This is the peer reviewed version of the following article: Stanišić M, Ćosić T, Savić J, Krstić-Milošević D, Mišić D, Smigocki A, Ninković S, Banjac N. Hairy root culture as a valuable tool for allelopathic studies in apple. Mock H-P, editor. Tree Physiol. 2019;39(5):888-905. https:// doi.org/10.1093/treephys/tpz006

$$
\begin{aligned}
& \text { (C) All Rights } \\
& \text { Reserved } \\
& \hline
\end{aligned}
$$

(C) The Author(s) 2019. Published by Oxford University Press. 


\section{Hairy root culture as a valuable tool for allelopathic studies in apple}

Mariana Stanišić ${ }^{1}$, Tatjana Ćosić ${ }^{1}$, Jelena Savić ${ }^{1}$, Dijana Krstić-Milošević ${ }^{1}$, Danijela Mišić ${ }^{1}$, Ann Smigocki $\stackrel{2}{ }$, Slavica Ninković ${ }^{\frac{1 *}{}}$, Nevena Banjac $\stackrel{1^{*}}{ }$

IInstitute for Biological Research "Siniša Stanković", University of Belgrade, Bulevar despota Stefana 142, 11060 Belgrade, Serbia

${ }^{2}$ USDA-ARS, Molecular Plant Pathology Laboratory, 10300 Baltimore Avenue, Beltsville, 20705, Maryland, USA

*equal contribution

Key words: Agrobacterium rhizogenes, allelopathy, Arabidopsis seedlings growth retardation, in vitro culture, apple hairy root exudate, polyphenols.

Corresponding author: Mariana Stanišić

University of Belgrade, Institute for Biological Research “Siniša Stanković”, Department for Plant Physiology, Despot Stefan Boulevard 142,11060 Belgrade, Serbia

Tel: +381 112078412

Fax: +381112761433

E-mail address: mariana.stanisic@ibiss.bg.ac.rs 


\section{Abstract}

Allelopathic plants exploit their chemical "weapons" to prevail the competition, suppress neighboring plants and consequently use the available resources more efficiently. However, the investigation of plant allelopathic interactions in rhizosphere is difficult to perform because of its high complexity due to interactions of biotic and abiotic factors. Thus, autonomous, aseptic roots cultures of apple (Malus $\times$ domestica Borkh.) could facilitate allelopathic studies. We report on the successful genetic transformation of apple cultivars Melrose, Golden Delicious, Čadel and Gloster using A. rhizogenes strain 15834 and for the first time the establishment of apple autonomous and permanent in vitro hairy root cultures that could be used as a new tool for apple allelopathic assays. Molecular characterization of transgenic hairy root lines was conducted to elucidate possible relationship between expression of T-DNA genes and root growth characteristics that include branching. Similar content of phenolic acids (chlorogenic, caffeic, syringic, $p$-coumaric and ferulic), glycosilated flavonoids (phloridzin, rutin, quercitrin, isoquercitrin, kaempferol-3-glucoside) and flavonoid aglycons (quercetin and naringenin) was detected in untransformed and transgenic apple root tissue by UHPLC/DAD/(+/-)HESI-MS/MS analyses, confirming that genetic transformation did not disturb secondary metabolite production in apple. Chlorogenic and caffeic acids and dihydrochalcones phloridzin and phloretin were detected as putative allelochemicals exuded into the growth medium in which transgenic roots were maintained for 4 weeks. Apple hairy root exudates significantly affected shoot and root development and growth of test plant Arabidopsis thaliana seedlings after 5 or 10 days of treatment. Additionally, core cell-cycle genes $C D K A 1 ; 1, C D K B 2 ; 1$, CYCA3;1 and CYCB2;4 were down regulated in Arabidopsis shoots suggesting, in part, their role in inhibition of shoot growth. Present work highlighted autonomous and permanent in vitro hairy root culture system as a valuable tool for studying allelopathic potential of apple, offering new perspective for allelopathy background elucidation in this important fruit species. 


\section{Introduction}

Apple (Malus $\times$ domestica Borkh) is a widely grown fruit tree with considerable economic importance, which recently has rapidly increased due to a growing demand for nutrient-rich dietary food. Traditional breeding has produced more than 7500 apple cultivars with a range of desirable characteristics. Some of the varieties like Melrose (Red Delicious $\times$ Jonagold), Gloster (Glockenäpfel $\times$ Ričared) and Čadel (Golden Delicious $\times$ Jonathan) are grown preferably for their good-quality fruits. Golden Delicious (Grimes Golden x Golden Reinette) is one of the oldest and most popular commercial and breeding cultivar in the world. Because of its economic importance, Golden Delicious was chosen for an apple genome sequencing project (Velasco et al. 2010) as a model cultivar to gain new knowledge or better understanding of traits important for breeding programs, improving fruit quality or studying other relevant apple traits.

Considering current eco-friendly trends in pest and weed management, the understanding the allelopathic capacity of herbaceous and woody crops is currently an important agricultural objective (Amb and Ahluwalia 2016). Allelopathy is known as an occasion where a plant species chemically interferes with the germination and growth of neighboring plants (Molisch 1937), or with the same plant (autoallelopathy). Although a considerable number of plants display allelopathic potential, allelopathy is not a common phenomenon in the plant kingdom. Plants that were characterized as allelopathic include black walnut(Juglans nigra) (Willis 2000), tree-ofheaven (Ailanthus altissima) (Heisey 1990), eucalyptus (Niakan and Saberi 2009) and Australian blackwood (Acacia melanoxylon) (Souto et al. 1994) trees. The dominant position of these tree species in forests significantly influenced plant biodiversity, e.g. vegetation diversity and composition (Bratton 1976; Palik and Engstrom 1999).

Allelopathic plants can exploit their metabolites to suppress neighboring plants, thus affecting vegetation diversity and lead to more efficient use of available resources (Zhang et al. 
2008; Jung et al. 2010). Apple allelochemical potential and identification of metabolites responsible for such properties could be of great importance for gaining new, scientific understanding of plant to plant interactions and for improving strategies to potentially control weeds in apple orchards or other agroecosystems. Allelopathic properties of apple trees are not well studied. Apple allelopathy has primarily been investigated as an effort to explain the phenomenon of ,specific apple replant disease $^{\text {" }}$ (SARD), characterized by stunted growth of apple trees that occurs after replanting on a land that previously supported the apple orchards (Börner 1959). Results of Zhang et al. (2007a) and Bai et al. (2009) indicated that root exudates of M. pumila and M. prunifolia can exhibit inhibitory influence on germination and seedling development of its own species. Despite very questionable etiology of SARD (Weiß et al. 2017; Mahnkopp et al. 2018), the phenolic compounds, including dihydrochalcones phloridzin and phloretin, exuded from apple roots into the soil or arisen by decomposition of the bark, leaves, fruits, roots or other tree parts, could be considered as the key factors involved in manifestation of SARD (Yin et al. 2016; Nicola et al. 2017; Yin et al. 2018).

Most allelochemicals classified as secondary metabolites are produced as offshoots of the primary metabolic pathways, and can be present in several parts of the plants. Apart from allelopathic interactions that occur in the aboveground plant organs such as leaves and stems, root to root interactions play an important role in the establishment and maintenance of plant communities (Bais et al. 2006). However, isolation and characterization of metabolites exuded from roots into the soil, as well as the exclusion of effects of other factors that are present in the soil during assessment of allelopathic properties is very complex. Thus, due to inevitable influence of microorganisms in the soil on chemicals secreted by plants, it is unclear whether allelopathic effects were induced by allelochemicals directly produced in plants, or after conversion of root exudates by microorganisms (Inderjit 2005). Hence, procurement of an aseptic bioassay system, where the examined materials are free from microbial activities, is important to evaluate the allelopathic effects. 
Hairy root cultures could be highly beneficial and effective for production and characterization of root secondary metabolites, evaluation of their phytotoxic effects, as well as for functional characterization and genetic manipulation of genes involved in the metabolism of root allelochemicals (Triplett et al. 2008; Kim et al. 2009; Mitić et al. 2012). Since Hoffmann et al. (2011) identified the Rosaceae roots as sites of expression of genes involved in flavonoid biosynthesis, establishment of apple hairy root cultures, capable of autonomous growth separately from shoots and without addition of plant growth regulators (PGR), could serve as a highly valuable system for studying allelopathy in apple.

Although hairy roots have been induced in more than 100 plant species, the proportion of woody species transformed using this system is very low (Christey, 2001). Susceptibility of Malus species to A. rhizogenes has been previously reported for apple rootstocks (Patena et al. 1988; Rugini and Mariotti 1992; Sutter and Luza 1993; Lambert et al. 1998; Pawlicki-Jullian et al. 2002; Yamashita et al. 2004; Wu et al. 2012). Therein, genetic transformation was used primarily to produce transgenic plants with dwarf attributes or improved rooting abilities.

The objective of the present work was to establish an in vitro assay system for studying allelochemicals in apple roots. For this purpose, domesticated apple cultivars Melrose, Golden Delicious, Čadel and Gloster were transformed using A. rhizogenes strain 15834 . Transgenic hairy root lines were used to elucidate the relationship between T-DNA gene expression and root growth characteristics such as branching. We also report on the influence of mineral solutions and auxins on hairy root growth and biomass production. To estimate utility of in vitro hairy root culture for apple allelopathic studies, the phytotoxic effects of apple hairy root exudates on test plant Arabidopsis thaliana, including effects on seed germination, seedling growth and expression of core cell cycle genes, cyclin-dependent kinases and cyclins, were investigated. 


\section{Material and methods}

\section{Agrobacterium rhizogenes strain}

Agrobacterium rhizogenes agropine strain 15834 harboring the pCAMBIA1301 binary vector (CAMBIA, Canberra, Australia) with the serine proteinase inhibitor gene from Beta vulgaris L. (BvSTI) (Smigocki et al. 2013) was used for transformation of apple. The full length BvSTI coding sequence was cloned behind the constitutive cauliflower mosaic virus 35S promoter (CaMV35S) (see Supplementary Figure 1). pCAMBIA1301 carries the hpt marker gene for selection of hygromycin $(\mathrm{Hg})$ resistant transformed plant cells with the nos polyadenylation signal. Bacterial cultures were maintained on solid YEB medium (Vervliet et al. 1975) supplemented with $50 \mathrm{mg} \mathrm{L}^{-1}$ kanamycin (Sigma-Aldrich St. Louis, MO, USA). To obtain bacterial suspension for explant inoculation, one full loop $(\varnothing 3 \mathrm{~mm})$ of cold stored bacterial culture were resuspended into 5 $\mathrm{mL}$ of sterile liquid YEB medium containing $50 \mathrm{mg} \mathrm{L}^{-1}$ kanamycin in $30 \mathrm{~mL}$ glass tubes $(18 \times 150$ $\mathrm{mm}$ ) and incubated on the orbital shaker at $95 \mathrm{rpm}$ for $24 \mathrm{~h}$ in the dark at $25 \pm 2{ }^{\circ} \mathrm{C}$, to an optical density of $\mathrm{OD}_{600} \approx 1.00$.

\section{Apple transformation and establishment of hairy root cultures}

Shoot cultures of apple cvs. Melrose, Golden Delicious, Gloster and Čadel, established from vegetative buds of one-year-old branches (Mitić et al. 2012) were used for genetic transformation. The cultires were grown on basal medium (BM) containing Murashige and Skoog (MS; 1962) mineral salts and Linsmaier and Skoog (LS; 1965) vitamins, 3\% (w/v) sucrose, $100 \mathrm{mg} \mathrm{L}^{-1}$ myoinositol and $0.7 \%(\mathrm{w} / \mathrm{v})$ agar, with addition of $0.5 \mathrm{mg} \mathrm{L}^{-1} N^{6}$-benzylaminopurine (BA) and $0.05 \mathrm{mg}$ $\mathrm{L}^{-1} \alpha$-naphthaleneacetic acid (NAA) (both from Sigma-Aldrich). Cultures were grown under the light (16-h photoperiod; $45 \mu \mathrm{mol} \mathrm{m} \mathrm{m}^{-2} \mathrm{~s}^{-1}$ ) in a growth room at $25 \pm 2{ }^{\circ} \mathrm{C}$ and subcultured at four-week intervals. 
Three-week old shoots, 2-3 cm long, were inoculated with A. rhizogenes either by: (i) wounding the stem with a sterile needle immersed in bacterial suspension at $1.5 \mathrm{~cm}$ from the basal end or by (ii) dipping the cut-edge of the shoot into the bacterial suspension for a few seconds. Transformation was performed on total of 313 apple shoots. Shoots used as a negative controls for transformation process itself were processed in the same way as inoculated explants, but they were inoculated with sterile liquid YEB medium instead Agrobacterium suspension.

The A. rhizogenes - inoculated shoots were placed on PGR-free BM medium, each shoot in separate $30 \mathrm{~mL}$ glass tube $(18 \times 150 \mathrm{~mm})$ under $16 \mathrm{~h}$ light photoperiod at $23{ }^{\circ} \mathrm{C}$. After three days of co-cultivation, shoots were transferred onto PGR-free BM medium supplemented with $500 \mathrm{mg} \mathrm{L}^{-1}$ cefotaxime (Tolycar; Jugomedija AD, Zrenjanin, Serbia) to eliminate Agrobacteria. Shoots with at least one hairy root at seven weeks after inoculation were considered putative transformants. Transformation efficiency was calculated as follows: (total number of hairy root lines/number of inoculated shoots) $\times 100$.

Each putative hairy root was established as an independently derived transformant. Twelve Golden Delicious, nine Čadel, three Gloster and 12 Melrose hairy roots were excised and propagated further as separate individual lines in $100 \mathrm{~mL}$ Erlenmeyer flasks in $50 \mathrm{~mL}$ of liquid BM media supplemented with $300 \mathrm{mg}$ cefotaxime $\mathrm{L}^{-1}$ on an orbital shaker at $95 \mathrm{rpm}$. Cefotaxime concentration was gradually reduced and finally omitted after 4 months of cultivation. Autonomous hairy root lines were maintained under the light (16-h photoperiod) provided by cool-white fluorescent tubes $\left(2 \mu \mathrm{mol} \mathrm{m} \mathrm{m}^{-2} \mathrm{~s}^{-1}\right)$ in a growth room at $25 \pm 2{ }^{\circ} \mathrm{C}$ and subcultured into cefotaximefree BM at 3-week intervals.

Untransformed control roots were obtained from rooted shoots, as described in Mitić et al. (2012). Three-week old shoots, 3-4 cm long, were placed on BM medium with $0.5 \mathrm{mg} \mathrm{L}{ }^{-1}$ IBA (indole-3-butyric acid). Shoots were grown five days in the dark and two days in the light (16-h 
photoperiod), and then transferred to PGR-free BM media where they were grown for six weeks until roots reached approximately $3-7 \mathrm{~cm}$ in length. Roots were excised from shoots and propagated in liquid half-strength BM $(1 / 2 \mathrm{BM})$ supplemented with $0.5 \mathrm{mg} \mathrm{L}^{-1}$ IBA on an orbital shaker under the same conditions as the hairy root cultures.

\section{Analysis of transgenes expression in putatively transformed hairy roots by RT-PCR}

Expression of genes from $\mathrm{T}_{\mathrm{L}}-\mathrm{DNA}\left(\operatorname{rolA}, \operatorname{rolB}\right.$, rolC, rolD) and $\mathrm{T}_{\mathrm{R}}-\mathrm{DNA}($ auxl, aux 2$)$ region of the Ri plasmid was analyzed in 28 hairy root lines and untransformed (control) roots by RT-PCR. Total RNA from $300 \mathrm{mg}$ of ground tissue was extracted in $100 \mathrm{mM}$ TRIS-HCl, pH $825 \mathrm{mM}$ EDTA, $2 \%$ CTAB (w/v), 2\% PVP (w/v), $2 \mathrm{M} \mathrm{NaCl}, 0.5 \mathrm{~g} \mathrm{~L}^{-1}$ spermidine and $2 \% \beta$-mercaptoethanol (v/v) (Gašic et al. 2004). Integrity and size distribution of purified total RNA were checked by agarose gel electrophoresis. DNase I (Thermo Scientific, Waltham, MA USA) was used to remove traces of DNA according to the manufacturer's protocol.

Reverse transcription (RT) of $400 \mathrm{ng}$ of DNase-free total RNA was carried out using RevertAid $^{\mathrm{TM}}$ Reverse Transcription Kit (Thermo Scientific) at $42{ }^{\circ} \mathrm{C}$ in a $20 \mu \mathrm{L}$ reactions. cDNA amplification was further performed in a volume of $25 \mu \mathrm{L}$ PCR mixture containing: $1 \mu \mathrm{L}$ of template cDNA (corresponding to $20 \mathrm{ng}$ total RNA), $1.25 \mu \mathrm{L}$ of $5 \mu \mathrm{M}$ forward and reverse gene specific primers (Table 1), $1 \mu \mathrm{L}$ of $10 \mathrm{mM}$ dNTPs, $0.25 \mu \mathrm{L}$ of $5 \mathrm{U}_{\mu \mathrm{L}^{-1} \text { AmpliTaq Gold }}^{\circledR}$ polymerase (Applied Biosystems), $0.75 \mu \mathrm{L}$ of $25 \mathrm{mM} \mathrm{MgCl}_{2}$ with $1.5 \mu 110 \times$ PCR buffer. To confirm the absence of residual A. rhizogenes in hairy root tissues, PCR using primers specific to the virDl gene (present in Ri plasmid outside the T-DNA region) was performed. Gene coding for M. domestica actin (MdActin) was used as internal control. RT and all PCR reactions were performed in Mastercycler $^{\circledR}$ nexus Gradient (Ependorf AG, Hamburg, Germany) PCR thermal cycler. The PCR program included initial denaturation $\left(95^{\circ} \mathrm{C}\right.$ for $\left.5 \mathrm{~min}\right), 40$ cycles of denaturation $\left(95^{\circ} \mathrm{C}\right.$ for $\left.30 \mathrm{~s}\right)$, 
annealing $\left(58{ }^{\circ} \mathrm{C}\right.$ or $60{ }^{\circ} \mathrm{C}$ for $\operatorname{aux} 2$ or all other genes, respectively, for $\left.1 \mathrm{~min}\right)$ and extension $\left(72{ }^{\circ} \mathrm{C}\right.$ for $1 \mathrm{~min})$, finally followed by extension $\left(72^{\circ} \mathrm{C}\right.$ for $\left.10 \mathrm{~min}\right)$. RT-PCR amplified gene products were analyzed by electrophoresis on 1.2-1.8\% (w/v) agarose (Sigma, St. Louis, MO) gels, depending on PCR product size, visualized with $0.5 \mu \mathrm{g} \mathrm{mL} \mathrm{m}^{-1}$ ethidium bromide (Valeant Pharmaceuticals, Montreal, Canada) staining and scanned by UltraLum Inc, Gel Exlorer, Exton, PA.

\section{Effect of mineral solutions and auxins on hairy root growth}

To increase the biomass production of apple hairy root cultures, the effects of 3liquid mineral solutions at full and half-strength were evaluated. Golden Delicious hairy root line GD12 was chosen for the experiment because it was able to produce sufficient amount of roots for the experimental design. All media were enriched with $3 \%$ sucrose, $100 \mathrm{mg} \mathrm{L}^{-1}$ myo-inositol and the same composition of vitamins according to Linsmaier and Skoog (1965), but with different composition of macro- and micro-salts. Thus, MS medium consisted of Murashige and Skoog (1962) salts, B5 of Gamborg et al. (1968) salts, while WPM consisted of woody plant medium (Lloyd and McCown 1981) macrosalts and MS microsalts. Approximately $500 \mathrm{mg}$ fresh weight (FW) of hairy root line GD12 harvested from three-week-old cultures was transferred into the 100$\mathrm{mL}$ Erlenmeyer flasks containing $50 \mathrm{~mL}$ of liquid MS, B5 or WPM media.

To evaluate the effect of auxins on hairy root growth, approximately $1 \mathrm{~g}$ of three-week-old hairy root line GD12 was harvested and transferred to $50 \mathrm{~mL}$ of MS liquid medium supplemented with either IBA or NAA at increasing concentrations $\left(0.01,0.025,0.05,0.1\right.$, and $\left.0.2 \mathrm{mg} \mathrm{L}^{-1}\right)$. Hairy root line GD12 grown in MS liquid medium without addition of auxins were used as a control. All cultures were maintained on a rotary shaker $(95 \mathrm{rpm})$ in a growth room under the same conditions as mentioned before. Media were replaced with fresh media at three weeks. At six weeks, roots were removed and blotted dry on filter paper and weighted under sterile conditions. The biomass 
increment was calculated as follows: biomass increment $(\%)=[$ fresh weight after six weeks of cultivation $(\mathrm{g})$ - fresh weight at the beginning of cultivation $(\mathrm{g})] /$ fresh weight at the beginning of cultivation $\times 100$. This experiment was repeated two times with three replicates (Erlenmeyer flasks) per treatment $(n=6)$.

\section{Secondary metabolite analyses in hairy roots and their exudates by UHPLC/(+/-)HESI-MS/MS}

Four week old untransformed and Golden Delicious GD12 hairy root grown in 1/2MS media were analysed for phenolic compounds by Ultra High Performance Liquid Chromatography with Mass Spectrometry (UHPLC/(+/-)HESI-MS/MS). Weighed roots were air-dried at room temperature $\left(23 \pm 2{ }^{\circ} \mathrm{C}\right)$ for seven days and weighted (DW). Roots were ground to fine powder in liquid nitrogen and $500 \mathrm{mg}$ was re-suspended in $30 \mathrm{~mL}$ of $80 \%$ methanol and placed in an ultrasonic bath for 20 minutes. After sonication, extracts were filtered and evaporated to dryness in vacuum rotary evaporator (Buchi R-210, Flawil, Switzerland) at $50{ }^{\circ} \mathrm{C}$. Dry extracts were stored at $4{ }^{\circ} \mathrm{C}$ until further analysis. The growth medium $(40 \mathrm{~mL})$ in which GD12 hairy root were grown for four weeks was collected for analysis and lyophilized (LH Leybold, Lyovac GT2/045, Frenkendorf, Switzerland) for five days. Samples were stored at $-80{ }^{\circ} \mathrm{C}$ for further analyses.

Identification and quantification of phenolic compounds were performed on Dionex Ultimate 3000 UHPLC system (Thermo Fisher Scientific, Bremen, Germany) configured with a triplequadrupole mass spectrometer (TSQ Quantum Access Max, Thermo Fisher Scientific, Basel, Switzerland). Phenolics were separated on Hypersil gold C18 (Thermo Fisher Scientific) column $(50 \mathrm{~mm} \times 2.1 \mathrm{~mm}$ i.d., $1.9 \mu \mathrm{m}$ particle size $)$, thermostated at $30{ }^{\circ} \mathrm{C}$. Mobile phase, consisting of 0.02\% acetic acid in water (A) and acetonitrile (B), was eluted according to Mišić et al. (2015). Flow rate was set to $0.4 \mathrm{~mL} \mathrm{~min}^{-1}$. The injection volume was $10 \mu \mathrm{L}$. Heated electrospray ionization (HESI) source of mass spectrometry was operated with vaporizer temperature of $300{ }^{\circ} \mathrm{C}$, spray 
voltage $4500 \mathrm{~V}$, sheet gas $\left(\mathrm{N}_{2}\right)$ pressure $35 \mathrm{AU}$, ion sweep gas pressure 1.0 AU and auxiliary gas pressure of $10 \mathrm{AU}$, capillary temperature at $275^{\circ} \mathrm{C}$, and skimmer offset $0 \mathrm{~V}$. Mass spectrometry data were acquired in a negative mode. Collision-induced fragmentation was performed using argon as the collision gas, and collision energy was set to $30 \mathrm{eV}$ for all the targeted phenolics. Quantification of targeted compounds in the samples was performed using Single Reaction Monitoring (SRM) mode of the instrument.

Identification of phenolic compounds in plant extracts was performed by comparison of their MS and $\mathrm{MS}^{2}$ spectra and retention times with those of the authentic standards, as well as by literature data search. Compounds were quantified by the external standard method. Standard mixture of pure compounds in methanol was prepared in concentration of $100 \mu \mathrm{g} \mathrm{mL} \mathrm{L}^{-1}$. Calibration levels $\left(100 \mu \mathrm{g} \mathrm{mL}^{-1}\right.$ to $\left.0.001 \mu \mathrm{g} \mathrm{mL} L^{-1}\right)$ were obtained by diluting the standard mixture with methanol. Regressions of the calibration curves showed good linearity with correlation coefficients between $r=0.990$ and $0.999, p<0.001$. Total amount of each targeted compound in the samples was determined by the calculation of peak area. Phenolics concentrations in root tissue were expressed as ng per mg of root dry weight (ng mg ${ }^{-1} \mathrm{DW}$ ), while their content in hairy root growth medium were expressed as ng exuded in $\mathrm{mL}$ of growth medium $\left(\mathrm{ng} \mathrm{mL}^{-1}\right)$ or exuded per $\mathrm{mg}$ of dry hairy roots $(\mathrm{ng}$ $\mathrm{mg}^{-1}$ DW). Standards of chlorogenic, caffeic, syringic, p-coumaric and ferulic, acid, and of phloridzin, phloretin, rutin, isoquercitrin, kaempferol-3-glucoside, quercitrin, quercetin and naringenin were purchased from Sigma-Aldrich (Steinheim, Germany).

Analysis of apple hairy root exudates on A. thaliana seedling germination, growth and development 
Liquid medium with 1/2MS mineral composition in which apple cv. Golden Delicious hairy root line GD12 was grown for four weeks was used to assess potential allelophatic effect on A. thaliana L. seedlings.

About 200 A. thaliana (L.) Heynh. ecotype Columbia (Col-0) seeds were surface sterilized with $70 \%(\mathrm{v} / \mathrm{v})$ ethanol and commercial bleach $(4-6 \% \mathrm{NaOCl})$ in $1: 1$ ratio for $60 \mathrm{~s}$ with shaking, washed four times in sterile distilled water for $60 \mathrm{~s}$, then immersed in sterile liquid 1/2MS medium and placed in the dark at $4^{\circ} \mathrm{C}$. After three days, seeds were transferred into $100-\mathrm{mL}$ glass Erlenmeyer flasks with $50 \mathrm{~mL}$ of liquid $1 / 2 \mathrm{MS}$ media containing hairy root line GD12 exudates or $1 / 2 \mathrm{MS}$ as a control. Seeds were cultivated on an orbital shaker $(95 \mathrm{rpm})$ under light $\left(45 \pm 2 \mu \mathrm{mol} \mathrm{m} \mathrm{s}^{-1}, 16-\mathrm{h}\right.$ photoperiod) in a growth chamber at $25 \pm 2{ }^{\circ} \mathrm{C}$. At 5 and 10 days, 10 seedlings were randomly selected and the number of lateral roots, shoots and the longest root length was measured. The bioassay was repeated two times using randomized design with three biological replicates (Erlenmeyers) for each treatment $(\mathrm{n}=60)$. The treatment effect (inhibition/stimulation) was calculated using the following formula: Effect $(\%)=[($ treatment/control $)-1] \times 100$. Negative $(-$ )/positive (+) values represent percentage of inhibition/stimulation compared to the control.

\section{Real time PCR (qPCR) analyses of cell cycle genes in A. thaliana}

Total RNA was isolated, as described above, from shoots and roots of A. thaliana seedlings grown for 10 days in liquid 1/2MS medium in which hairy roots of line GD12 were previously maintained for four weeks or $1 / 2 \mathrm{MS}$ medium (control). Each sample consisted of pooled shoots or roots germinated from 400 seeds. Samples were collected in three biological replicates. The subsequent DNase I treatment and reverse transcription of RNA were performed using a RevertAid $^{\mathrm{TM}}$ Reverse Transcription Kit (Thermo Scientific), as described above. Derived cDNA was used for qPCR with QuantStudio 3 Real-Time PCR System (Applied Biosystems) and Maxima 
SYBR Green/ROX Kit (Thermo Scientific), per manufacturer's instruction. Each $10 \mu \mathrm{L}-\mathrm{PCR}$ reaction was comprised of $5 \mu \mathrm{L}$ of the qPCR Master Mix, $1 \mu \mathrm{L}$ cDNA (corresponding to $10 \mathrm{ng}$ total RNA) and $0.6 \mu \mathrm{L}$ of $5 \mu \mathrm{M}$ forward and reverse primers each for specific gene amplification. The primers used for $C D K A 1 ; 1, C D K B 2 ; 1, C Y C A 3 ; 1$, and $C Y C B 2 ; 4$ gene amplification are presented in Table 2. A. thaliana actin gene (ACTIN7) (Table 2) was used as reference gene. All primers correspond to a particular A. thaliana gene in GenBank ${ }^{\mathrm{TM}}$. Specificity of all primers used was confirmed by BLAST, RT-PCR products, and analysis of melting curves during qPCR.

qPCR reaction conditions were $95{ }^{\circ} \mathrm{C}$ for $5 \mathrm{~min}$; followed by 40 cycles of denaturation at 95 ${ }^{\circ} \mathrm{C}$ for $30 \mathrm{~s}$, annealing at $60{ }^{\circ} \mathrm{C}$ for $1 \mathrm{~min}$, and extension at $72{ }^{\circ} \mathrm{C}$ for $1 \mathrm{~min}$, with final extension at $72{ }^{\circ} \mathrm{C}$ for $10 \mathrm{~min}$. For each sample, qPCR reactions were carried out in technical triplicate. The results were analyzed using QuantStudio Design \& Analysis Software v1.4.2 (Applied Biosystems).

The expression level for CDKA1;1, CDKB2;1, CYCA3;1 and CYCB2;4 genes under the influence of apple hairy root exudates were calculated relative to an expression of non-treated control according to the $\Delta \Delta \mathrm{Ct}$ method (Livak and Schmittgen 2001), and presented as a $\log _{2}$ transformation of fold changes.

\section{Data analyses}

All experiments were set up in a randomized design. The percentage data were subjected to angular transformation and the lateral roots number data to square root transformation before statistical analysis, followed by inverse transformation for presentation. The data for hairy root biomass increase influenced by type of medium or auxins were subjected to one-way analysis of variance (ANOVA). The means were subjected to post hoc Fisher's least significant difference (LSD) test. Differences between means of phenolic compound content in untransformed roots and hairy roots, as well as between means of morphological parameters of control Arabidopsis seedlings 
and seedlings treated with apple hairy root exudates, were evaluated by the $t$-test for dependent samples. For all analyses the confidence level was $\mathrm{P}<0.05$. All data were analyzed by SAS software (SAS Institute, 2002; SAS/STAT, ver. 9.00. SAS Institute Inc., Cary, NC, USA).

\section{Results}

\section{Induction, culture establishment and growth pattern of transgenic apple hairy roots}

Hairy roots of apple cvs. Melrose, Golden Delicious, Čadel and Gloster were initiated by inoculation of in vitro grown shoots using A. rhizogenes strain 15834. Two inoculation procedures were applied: shoot stem wounding by infected needle or dipping the basal cut end of the stem into bacterial suspension. Appearance of hairy roots on shoots was scored two weeks after infection regardless of the inoculation method. Inoculation by stem wounding incited emergence of hairy roots directly from the wound sites (Fig. 1), while basal cut inoculation induced root growth from the cut-edges and surrounding tissues, as high as 10-20 $\mathrm{mm}$ upstream from the basal end of the stem (Fig. 2A). In a few cases, roots appeared on the leaf surface (Fig. 2A). Pale, loose calli were often present at the sites of agrobacterial inoculation on shoots that did not produce roots. New hairy roots emerged over a five week period while existing ones continued to grow, reaching up to $12 \mathrm{~cm}$ in length.

Most roots displayed apparent agravitropic response, with some of them growing upward, forming loops (Fig. 2B). Larger lateral roots were occasionally fused together at their base forming irregular shape structures that frequently exhibited callus growth at the surface (Fig 2C). Most roots were thick and white, sometimes with light pink coloration (Fig. 2D) or with yellow tinge (Fig. 2E). Lateral roots without root hairs were sparsely emerged along the roots. A few hairy root lines were observed without or only with 1-2 lateral roots spreading along the axial root. Often, callus was present on the whole surface of the regenerated roots (Fig. 2C; $2 \mathrm{~F}$ ). 
Unlike the hairy root morphology that was cultivar independent, transformation efficiencies were dependent on both the cultivar and the inoculation method (Table 3). Melrose cultivar gave the highest transformation efficiency of $70.2 \%$ on wounded stems and $3.3 \%$, when the basal end was inoculated by dipping. In contrast, the dipping method proved to be more efficient in cv. Golden Delicious (39.3\%), and the only one that enabled successful transformation of cvs. Čadel and Gloster at $30 \%$ and $10 \%$, respectively.

Seven weeks after inoculation, hairy roots were excised from the shoot explants and cultured as individual lines. Characteristic hairy root phenotypes were observed with varying degrees of branching, growth rate and biomass production. A few hairy root lines were fast growing and highly branched (Fig. 3A and B), while majority of them were characterized by slower growth of axial roots, poor branching and low biomass accumulation (Fig. 3C and D). Eight lines turned brown and died shortly after excision from the shoots or during the first four months of individual cultivation. Thus, from total of 36 hairy root lines, 28 survived and were subjected to molecular analyses to confirm successful integration and expression of T-DNA transgenes. No roots regenerated from control apple shoots inoculated with agrobacteria-free sterile liquid YEB. Control root lines were established by rooting apple shoots on medium supplemented with the auxin IBA (Fig. 3E). Roots that developed and were excised and propagated in PGR-free medium turned brown and died soon after. Only untransformed roots grown on IBA produced large number of lateral roots. Few weeks later, lateral root formation declined considerably and biomass increased only from the apical growth of existing roots. Those in vitro cultures had long, thin and not branched roots that were visually distinct from the transgenic hairy root phenotypes (Fig. 3F). After several months of cultivation, roots became yellow, started to callus and did not survive.

\section{Gene expression in transgenic hairy roots}


Molecular analyses revealed that all 28 analyzed hairy root lines were not contaminated with A. rhizogenes since RT-PCR analysis detected no virDl gene transcripts (Table 4). Analysis for expression of genes from $\mathrm{T}_{\mathrm{L}}$-DNA (rolA, $\operatorname{rolB}, \operatorname{rol} C$, rolD) in the transgenic hairy roots revealed that the complete $\mathrm{T}_{\mathrm{L}}$-DNA region was integrated and the rol gene transcripts present, confirming the transgenic nature of the hairy root lines (Table 4 and Supplementary Figures 2, 3, 4 and 5). On the other hand, the auxl and aux2 genes from $\mathrm{T}_{\mathrm{R}}$-DNA were sporadically expressed (Table 4 and Supplementary Figures 2, 3, 4 and 5). The expression of both aux1 and aux2 genes was detected in only three lines (M2, M6 and GD3), while 10 hairy root lines expressed neither of these two genes (Table 4). Untransformed roots (control) had very low and hardly detectable background signals of the rolA gene in cultivar Melrose, rolC in Golden Delicious and Gloster, and rolD in Čadel and Gloster (Table 4 and Supplementary Figures 2, 3, 4 and 5).

\section{The effect of mineral solutions and auxins on apple hairy root growth}

In general, majority of the autonomously growing hairy root lines were characterized by poor yield of biomass following one subculture period thus necessitating optimization of the cultivation protocol. Since Golden Delicious line GD12 displayed constant growth in PGR-free BM medium to provide enough plant material, it was selected for experiments to assess the effect of different mineral solutions and auxins on root growth. GD12 root growth in MS, 1/2MS, WPM, $1 / 2$ WPM, B5 and $1 / 2$ B5 was slow during the first two weeks of cultivation followed by more rapid growth especially in $1 / 2 \mathrm{MS}$ and $1 / 2 \mathrm{~B} 5$ media. After six weeks of cultivation in $1 / 2 \mathrm{MS}$, GD12 roots displayed the most vigorous growth and branching, producing the highest fresh weight increase (231\%), compared to other mineral solutions (165\% and below, Fig. 4A). No statistically significant differences $(\mathrm{P} \leq 0.05)$ in root fresh weight increase were noted between $1 / 2 \mathrm{MS}$ and $1 / 2 \mathrm{~B} 5$ treatment, 
however, GD12 hairy roots turned brown after second subculture in $1 / 2 \mathrm{~B} 5$ unlike those in $1 / 2 \mathrm{MS}$. Thus, $1 / 2 \mathrm{MS}$ mineral solution was chosen for micropropagation of the apple hairy root lines.

To further accelerate the growth of apple hairy roots, the effect of IBA and NAA at increasing concentrations was tested (Fig. 4B). Auxins influenced branching and the growth rate. Relative to the auxin-free control (93\% biomass increase), the highest increase in biomass was observed in $1 / 2 \mathrm{MS}$ media supplemented with NAA at $0.1 \mathrm{mg} \mathrm{L}^{-1}(455 \%)$ and IBA at $0.025 \mathrm{mg} \mathrm{L}^{-1}$ (435\%). Despite the initial intense growth stimulated by $0.1 \mathrm{mg} \mathrm{L}^{-1} \mathrm{NAA}$, prolonged cultivation in this medium induced callus formation that arrested root elongation and branching, causing root tissue death. Overall, NAA supplementation induced more root callus formation than IBA. Thus, lower concentrations of IBA (0.01 to $\left.0.025 \mathrm{mg} \mathrm{L}^{-1}\right)$ were more appropriate options for root growth and branching. However, prolonged root cultivation with IBA also induced some degree of callus formation with an effect on root growth. Thus, for continued cultivation and maintenance of slowgrowing lines, roots should be grown by shifting between IBA-containing and IBA-free media.

\section{UHPLC/(+/-)HESI-MS/MS analysis of phenolic compounds in apple hairy root tissue and} growth medium

Phenolic acids (chlorogenic, caffeic, syringic, p-coumaric and ferulic), glycosilated flavonoids (phloridzin, rutin, quercitrin, isoquercitrin, kaempferol-3-glucoside) and flavonoid aglycons (floretin, quercetin and naringenin) were detected by UHPLC/(+/-)HESI-MS/MS analyses in untransformed apple cultivar Golden Delicious roots, GD12 hairy root line and growth medium in which GD12 roots were cultivated for four weeks (Table 5).

In both untransformed and hairy roots, phloridzin was the predominant phenolic compound with 1763.83 and $2643.60 \mathrm{ng} \mathrm{mg}^{-1} \mathrm{DW}$, respectively, being about 100 - to 1000 -fold higher than the 
other phenolics (Table 5). Phloridzin aglycon - phloretin was not detected, while other two aglycons, quercetin and naringenin were present in trace amounts and could not be quantified.

Seven compounds were detected in the growth media of line GD12, but only four (chlorogenic and caffeic acids, phloridzin and phloretin) in concentration that could be quantified (Table 5). Phloridzin concentration was about 500 times lower than in roots, but in the same range as phloretin and phenolic acids.

\section{Allelopathic effect of apple hairy root exudates on A. thaliana seedlings}

Apple hairy root exudates did not have an effect on A. thaliana seed germination. After five and 10 days of treatment, however, root and shoot growth was significantly affected as compared to untreated controls (Fig. 5 and 6).

In control seedlings, white, thin and short lateral roots were observed five days after exposure to light, with an average 1.94 lateral roots per seedling (Fig. 6A). Lateral roots formed mainly on the upper third of the axial root with no root hairs. In contrast, exudate treated seedlings rarely formed lateral roots (0.18 lateral root/seedling). Over the next five days, thin lateral roots did emerge (9.6 lateral root/seedling), but they were much shorter, not branched and with less root hairs than on controls (36.8 lateral roots/seedling). Apple root exudates not only inhibited lateral root formation (74\%), but also significantly inhibited elongation of axilar roots (35.15\%) (Fig. 6B).

Arabidopsis shoot morphology was affected by the hairy root exudates. Shoot length was reduced by almost $50 \%$ at five days of treatment, increasing to $62.1 \%$ at 10 days (Fig. 6C). Only cotyledons were visible in treated seedlings compared to control seedlings that had, in addition to cotyledons, two completely developed leaves and a second pair emerging from the bud. In addition, leaves were smaller and pale as compared to the controls (Fig. 5). 


\section{Exudate effect on A. thaliana cell cycle related genes}

Expression levels of cyclin-dependent kinases (CDKA1;1, and $C D K B 2 ; 1)$ and cyclins (CYCA3;1 and CYCB2;4) genes were analysed in A. thaliana shoots and roots treated for 10 days with apple hairy root exudates.

Apple hairy root exudates did not affect expression levels of analysed genes in roots, but gene transcript levels were reduced in shoots, with the highest descent in expression observed for CDKA1;1 and CYCB2;4 (Fig.7).

\section{Discussion}

Transformation of members of Malus genus by A. rhizogenes has been applied mainly to improve the rooting capacity of apple rootstocks (Pawlicki-Jullian et al. 2002; Yamashita et al. 2004; Wu et al. 2012). Accordingly, there have been no attempts to isolate hairy roots from mother plants and to cultivate them as individual root cultures. In this study, we report on transformation of

apple cultivars Melrose, Golden Delicious, Čadel and Gloster using A. rhizogenes 15834 that, for the first time, establishes in vitro propagated hairy root cultures of apple.

Several factors have been found to affect transformation efficiency of fruit trees (Petri and Burgos 2005). Among them, genotype remains the most serious limiting factor for gene transfer to fruit crops. Similarly, we expected that the transformation efficiency in this study would be apple cultivar dependent, but as it turns out the Agrobacterum inoculation method proved to be equally important. Wounding of Melrose stems with A. rhizogenes gave the best transformation efficiency (70.2\%) compared to $3.3 \%$ when basal cut end of the shoots was dipped into bacterial suspension. Although inoculation by wounding with infected needle or scalpel is a widely used method (Gutièrrez-Pesce et al. 1998; Vinterhalter et al. 2006; Ninković et al. 2010; Bogdanović et al. 2014), 
the dipping method proved to be more efficient in cv. Golden Delicious (39.3\%), as well as the only way that cvs. Čadel and Gloster (30\% and $10 \%$, respectively) were successfully transformed. This method was successfully used to transform Malus baccata (Wu et al. 2012) and Jork 9 (PawlickiJullian et al. 2002) apple rootstocks. In Jork 9, transformation frequencies of 16.7 to $77.8 \%$ were dependent on the strain of $A$. rhizogenes used, strain 15834 giving the lowest efficiency (PawlickiJullian et al. 2002). Using the same strain and dipping method in our study, we obtained efficiencies of up to $39.3 \%$ in Golden Delicious. Application of this method favored not only hairy root formation from the stem cut-edges, but also upstream from the basal end of the shoot, on the stem and leaf. This could be the consequence of agrobacteria infection of leaf cells that were wounded accidentally during manipulation, or by penetration of xylem and phloem elements on the cut-edges, reaching damaged cells at a distance.

Although possessed an apparent agravitropic response, majority of the apple hairy root lines were slow growing, with sparse lateral roots distributed along the axial root and lacking root hairs that commonly characterize hairy root phenotypes (Tepfer and Casse-Delbart 1987). This morphology could be the specificity of the Malus genotype since hairy roots with similar phenotypes were also obtained with Malus pumila, Jork 9 and Malus baccata rootstocks (Sutter and Luza 1993; Pawlicki-Jullian et al. 2002; Wu et al. 2012). The degree of hairy root branching and biomass increase was more notable after roots were excised from the shoots and cultivated as individual lines. This phenomenon was reported for hairy root cultures derived from a wide range of plant species (Chaudhuri et al. 2005; Tiwari et al. 2007; Taneja et al. 2010; Mitić et al. 2012). These differences appear to be specific to the hairy root line itself, since the different characteristics were found in lines that originated from the same shoot. Some authors suggested that these alterations are a consequence of the variable integration of genes from $\mathrm{T}_{\mathrm{L}^{-}}$and $\mathrm{T}_{\mathrm{R}}$-DNA into the plant genome (Batra et al. 2004; Tiwari et al. 2007; Taneja et al. 2010). Nevertheless, in our work molecular 
analysis did not reveal any correlation between expression of rol and aux genes and growth characteristics of apple hairy root lines. Lines that did not express one or both of aux genes were incapable to produce enzymes involved in auxin biosynthetic pathway (tryptophan monooxygenase or/and indole-3-acetamide hydrolase), thus to synthesize IAA, but differed greatly in growth characteristics. Similar phenomenon was observed in hairy root cultures of Catharanthus roseus (Batra et al. 2004; Taneja et al. 2010). Based on the presented results it could be concluded that genes from $T_{R}$-DNA were not responsible for growth characteristics of hairy roots in apple. Since all four rol genes (rolA, B, C and $D$ gene) were expressed in all of the 28 analyzed hairy root lines, additional analysis using Real time PCR (qPCR) would be necessary for determination of precise rol genes expression level, and elucidation of its possible relation with hairy root branching and growth. Additionally, explanation could be sought in other factors such as transgene copy number, position effects or epigenetic control. Since it is known that rolB expression is largely auxin-inducible, and in turn, fate of rolB induced meristem depends upon the local hormonal balance of the cell (Baumann et al. 1999), difference among hairy root lines could be the consequence of their origin from different initially infected cells, characterized by the different hormone level and/or sensitivity. Additionally, Alpizar et al. (2008) and Taneja et al. (2010) reported sporadic lack of integration of individual rol genes from $\mathrm{T}_{\mathrm{L}}$-DNA in coffee and Catharanthus roseus, while $\mathrm{T}_{\mathrm{R}}$-DNA was always completely integrated or completely missing. In contrast, in our study, all rol genes from $\mathrm{T}_{\mathrm{L}}-\mathrm{DNA}$ were always integrated together, while integration of aux genes was sporadic.

The low intensity signals detected by RT-PCR for rolA, rolC, and rolD gene in our untransformed control roots of all four apple cultivars could be explained by possible ancient transfer between A. rhizogenes and apple ancestor. This phenomenon was suggested by hybridization of probes specific to $\mathrm{T}_{\mathrm{L}^{-}}$and $\mathrm{T}_{\mathrm{R}}$-regions of T-DNA to untransformed apple rootstock M26 DNA restriction fragments (Lambert and Tepfer 1992). Similar phenomenon was also 
observed in genus Nicotiana (White et al. 1983; Meyer et al. 1995; Fründt et al. 1998), as well as in Convolvulus arvensis (Tepfer 1983) and Ajuga reptans (Tanaka et al. 1998).

Half-strength MS (1/2MS) medium was found to induce the highest level of growth $(231 \%)$ in apple transgenic line GD12. The same mineral solution proved to be the most suitable for hairy root cultures of Fagopyrum esculentum (Lee et al. 2007), while maximum biomass increase of Panax hibride (Washida et al. 1998) and Platycodon grandiflorum (Tada et al. 1995) hairy roots was achieved on B5 media, suggesting that the content and concentration of macro and micro nutrients is species specific.

Transgenic hairy roots are characterized by high branching and intense growth due to their increased sensitivity to auxins caused by activity of the rolB gene (Shen et al. 1988; Nilsson and Olsson 1997; Baumann et al. 1999). Thus, addition of exogenous auxins to culture media might have positive or adverse effects on hairy root growth, depending on the concentration and type of auxin applied (Liu et al. 2002; Alpizar et al. 2008). We found that supplementing the growth medium with lower concentration of IBA $\left(0.01 \mathrm{mg} \mathrm{L}^{-1}\right.$ or $\left.0.025 \mathrm{mg} \mathrm{L}^{-1}\right)$ stimulated most branching and elongation of lateral roots with increasing biomass accumulation, while higher concentrations $\left(0.1 \mathrm{mgL}^{-1}\right.$ or $\left.0.2 \mathrm{mg} \mathrm{L}^{-1}\right)$ did not have a positive effect on root growth. On the contrary, higher concentration of IBA, $0.1 \mathrm{mg} \mathrm{L}^{-1}$ (Alpizar et al. 2008) and $0.5 \mathrm{mg} \mathrm{L}^{-1}$ (Washida et al. 1998), were the most effective in stimulating hairy root branching and growth in coffee and Panax hybrid, respectively. Liu et al. (2002) reported that Pueraria lobata hairy root growth and lateral root elongation was stimulated at $0.02 \mathrm{mg} \mathrm{L}^{-1}$, not effected at $0.2 \mathrm{mg} \mathrm{L}^{-1}$, and inhibited at $0.5 \mathrm{mg} \mathrm{L}^{-1} \mathrm{IBA}$. It appears that the endogenous content of auxin, characteristic for every species, dictates the extent to which exogenous auxins could stimulate the lateral root branching and growth. Additionally, inhibitory effect of higher auxin concentrations could be the result of altered signaling responses of other endogenous hormones involved in the regulation of lateral root development and growth, like 
cytokinins (as reviewed by Su et al. 2011) and gibberellins (Fu and Harberd 2003; Gou et al. 2010). The results also revealed that hairy root callusing in apple was more pronounced in the case of NAA than at the same concentrations of IBA. A similar observation was reported in hairy root cultures of opium poppy and Karwinskia humboldtiana, (Park and Facchini 2000; Kollárová et al. 2004). Although in apple hairy roots IBA at lower concentrations $0.01 \mathrm{mg} \mathrm{L}^{-1}$ and $0.025 \mathrm{mg} \mathrm{L}^{-1}$ stimulated initiation and growth of lateral roots, longer period of exposure led to increased callusing and consequently reduced hairy root growth. Therefore, the liquid $1 / 2 \mathrm{MS}$ medium with the addition of IBA at $0.025 \mathrm{mg} \mathrm{L}^{-1}$ was chosen for initial stimulation of growth of hairy roots after their excision from primary explants, while prolonged cultivation was carried out in the PGR-free liquid 1/2MS medium. For prolonged cultivation and maintenance of slow growing lines, the altering of IBAcontaining and IBA-free media is recommended.

In light of the crucial impact of auxins on plant physiology (Teale et al. 2006; Péret et al. 2009; Kieffer et al. 2010), absence of auxins in apple root culture medium would be important for investigating allelopathic potential of apple trees. Since untransformed apple roots would not survive and grow without IBA supplementation, satisfactory constant growth of apple hairy roots in the absence of PGRs, like hairy root line GD12, should be of particular importance for chemical characterization of apple exudates and for application in bioassays.

Phenolic compounds are considered potent allelochemicals in most plant species ( $\mathrm{Li}$ et al. 2010). Many polyphenolic compounds have been detected in roots, leaves, bark, fruits and seeds of domesticated apple (Hunter and Hull 1993; Awad et al. 2000; Treutter 2001; Pontais et al. 2008). Some of them were also found in the soil in which apple trees were grown, or in the close distance of the trees as a result of decomposition of apple tissues or the apple tree root exudation (Hofmann et al. 2009; Yin et al. 2016). 
UHPLC/(+/-)HESI-MS/MS analyses showed the presence of phenolic acids, chlorogenic and caffeic, as well as dihydrochalcones phloridzin and phloretin as putative allelochemicals exuded by hairy root line GD12 into the growth medium. In hairy root GD12 and GD untransformed control roots, a larger number of phenolic compounds were detected, indicating that not all of synthesized compounds were being secreted. Even though rol genes are capable of altering intensity of secondary metabolite production in transformed plants (Bonhomme et al. 2000; Kiselev et al. 2007; Shkryl et al. 2008), similar content of phenolics detected in untransformed and transgenic apple root tissue indicated that Agrobacterium-mediated genetic transformation did not disturb phenolic secondary metabolite production in apple hairy root. Phloridzin was recognized as the most abundant of all phenolics in apple root tissues, with concentration that was from 100- to 1000-fold higher than content of other detected compounds. Predominance of phloridzin was commonly found in other apple tissues (Hunter and Hull 1993; Treutter 2001; Pontais et al. 2008). Since the dry weight of apple hairy roots is approximately $10 \%$ of the FW, phloridzin content in hairy root GD12 is approximately $0.3 \mathrm{mg} \mathrm{g}^{-1} \mathrm{FW}$, similar to untransformed roots of in vitro grown $\mathrm{cv}$. Liberty and McIntosh apple shoots (0.4 to $1.2 \mathrm{mg} \mathrm{g}^{-1} \mathrm{FW}$ ) (Hrazdina 2003). Despite the high amounts of phloridzin detected in the hairy root tissue, less than one percent $(\sim 0.13 \%)$ of its content was released into the growth medium. Nevertheless, the content of phloridzin secreted from hairy roots into the growth medium is similar to that released from roots of apple plants grown in the soil (Hofmann et al. 2009).

Interestingly, phloretin, a phloridzin precursor which is glycosylated in apple tissues by phloretin 2'-O-glycosyltransferase forming phloridzin (phloretin 2'-O- $\beta$-D-glucopyranosid) (Jugdé et al. 2008: Gosch et al. 2010), was not detected in roots. Likewise, Hrazdina (2003) did not detect phloretin in stems and roots of McIntosh and Liberty cultivars. No phloretin was detected in leaves of 14 different M. domestica cultivars (Mikulic-Petkovšek et al. 2009). Hairy root GD12, in addition 
to the phloridzin, contained only glycosylated forms of other flavonoids that included rutin, quercitrin, isoquercitrin and kaempferol-3-glucoside, while aglycons like floretin, quercetin and naringenin were not present or were detected in trace amounts. Taken together, this suggests that plants strive to rapidly convert newly synthesized metabolites, like dehydrochalcones and other flavonoids, into soluble glycosylated forms and stored them in the form of more stabile pools (Jones and Vogt 2001). This process enables plants to control the quantity of physiologically active metabolites and the overall dynamics of physiological processes, and for self-protection from toxic endogenous and exogenous substances (Sirikantaramas et al. 2008). Flavonoids like quercetin could act as mutagens or cause fragmentation of some tryptophan-containing proteins (Ahmed et al. 1994; Rueff et al. 1995). It was known that pyrolisis of tryptophan resulted in more mutagenic activity than did any other common amino acid (Matsumoto et al. 1977). Expectedly, plant might convert flavonoids into glycosylated forms and actively transport them into vacuoles (Klein et al. 2006).

It is well documented that phloridzin is prone to degradation by enzymes produced by soil microorganisms (Jayasankar et al. 1969; Chatterjee and Gibbins 1969; Natsume et al. 1982). In the aseptic conditions of hairy root in vitro culture, it is possible that phloridzin was aglycosylated spontaneously, or due to activity of the apoplastic glycoside hydrolases (Günl et al. 2011) or cytosol $\beta$-glycosidases (Warzecha et al. 1999; Czjzek et al. 2000), released from root cells after their damage or necrosis.

Within $M$. domestica, the concentration of dihydrochalcones can vary depending on the cultivar ( ata et al. 2009), tissue (reviewed by Gosh et al. 2010), developmental stage (Zhang et al. 2007b) and sampling time (Hunter and Hull 1993; Mikulic-Petkovšek et al. 2009). Environmental factors like seasonal changes and pathogens also may affect phloridzin content in the same type of apple tissue (Mikulic-Petkovšek et al. 2008). In vitro hairy root cultures eliminate environmental factors and pathogens, providing stable growing conditions. In addition, they mimick natural 
dynamics in metabolism of dihydrochalcones. Accordingly, this system approved to be suitable for studying the allelopathic potential of dihydrochalcones and other phenolics in apple. Additionally, secretion of phloridzin, chlorogenic and caffeic acid from hairy root cultures growing separately from shoots, confirms that apple roots are not only the sink in which the chemicals accumulate when transported from the shoots but also are the primary site of synthesis of these phenolic substances. This justifies the use of hairy root culture not only as a tool for studying allelopathy, but also for functional characterization of genes involved in biosynthesis of these compounds and for genetic manipulations to enhance apple allelopathic attributes by improving allelochemical production (Bourgaud et al. 2001).

To study the allelopathic potential of apple root exudates, A. thaliana was chosen as it previously was shown to be a sensitive test plant suitable for allelopathic assays (Pennacchio et al. 2005) and for examining genomic responses (Bais et al. 2003). In contrast to numerous allelochemicals that inhibited Arabidopsis seed germination (Pennacchio et al. 2005; Reigosa and Pazos-Malvido 2007), apple hairy root exudates did not inhibit germination but did significantly affect seedling growth. The strongest inhibitory effect was on the formation of lateral roots $(74.0 \%$ inhibition). Root elongation and shoot growth were also significantly affected $(35.1 \%$ and $62.1 \%$ reduced, respectively). Moreover, apple root exudates disrupted the morphology of Arabidopsis shoots and leaves. That phenolic compounds like chlorogenic and caffeic acid are plant allelochemicals have already been documented by a number of authors (Patterson 1981; Garg and Garg 1989; Reigosa and Pazos-Malvido 2007; Batish et al. 2008). Aqueous extract of Delonix regia, an ornamental tree of Taiwan, containing several phenolic compounds including chlorogenic and caffeic acid, exhibited profound inhibitory effect on growth of lettuce (Lactuca sativa), Chinese cabbage (Brassica chinensis) and alfalfa (Medicago sativa) (Chou and Leu 1992) at various concentrations. Caffeic acid exhibited inhibitory effect on mung bean (Phaseolus aureus) seedling 
root, shoot elongation and biomass increase (Batish et al. 2008). In A. thaliana, 10-1000 $\mu \mathrm{M}$ chlorogenic acid did not influence germination rate but significantly decreased seedling root elongation (Reigosa and Pazos-Malvido 2007), while caffeic acid inhibited Arabidopsis germination by 1.5 to $100 \%$ depending on its concentration (1-100 mM) (Pennacchio et al. 2005). Considering that the contribution of phenolic compounds to allelopathy was usually not the result of a single substance (Einhellig et al. 2004), the role and the allelopathic activity of dihidrochalcones phloridzin and phloretin needs to be explored, especially in light of their involvement in the phenomenon known as "specific apple replant disease" (Nicola et al. 2017; Yin et al. 2016). Recent overview on this phenomenon is close to the early statement of Börner (1959) who associated SARD with autoallelopathy, implying the chemicals released from apple roots into the rhizosphere, by exudation or decomposition of roots, bark or leaves, interfere with the germination and growth of neighbouring individuals (Zhang et al. 2007a; Bai et al. 2009). The treatment of Fuji apple seedlings with mixture of unaffected soil and grounded roots of rootstock M26 caused significant inhibition of seedling growth and decrease in chlorophyll content (Nicola et al. 2017). This allelopathic effect authors primarily attributed to phloridzin as conceivably dominant phenolic compound detected in soil/roots mixture. The apple transgenic hairy root culture could be convenient method to study prospective autoallelopathy role of apple allelohemicals exuded from roots, by testing their autotoxicity on apple seed germination and seedlings growth in vitro.

Retardation of Arabidopsis shoot and root growth and lateral root formation affected by apple hairy root exudates can be the result of disturbance of diverse physiological and biochemical processes (Weir et al. 2004). Thereby, many plant allelochemicals have frequently been reported to retard cell division (Nishida et al. 2005; Sánchez-Moreiras et al. 2008; Zhang et al. 2010; Soltys et al. 2011; Mitić et al. 2012; Dmitrović et al. 2015). Although, nearly 200 genes are involved in regulating the cell cycle in Arabidopsis, central role belongs to core cell cycle genes (cyclins and 
cyclin-dependent kinases) (Menges et al. 2005; Van Leene et al. 2010). Two cyclin-dependent kinases CDKA1;1 and CDKB2;1 and cyclins CYCA3;1 and CYCB2;4 were chosen for our experiments. Kinase CDKA1;1 which is constitutively expressed to regulate the entrance to the cell cycle, as well as both the G1-to-S and G2-to-M transitions, is postulated to interact exclusively with type D cyclins (CYCD) and specific S-phase cyclins type A, like CYCA3;1 (Vandepoele et al. 2002; Van Leene et al. 2010). Cyclin-dependent kinase CDKB2;1 and cyclin CYCB2;4 are involved in the control of the G2-to-M checkpoint (Menges et al. 2005). Additionaly, research of Lee et al. (2003) indicated that rice CDKB2;1 interacts exclusively with B2 cyclins. Our treatment of A. thaliana shoots with apple hairy root exudates caused down-regulation of the $C D K A 1 ; 1$ and $C D K B 2 ; 1$ cyclin-dependent kinases and $C Y C A 3 ; 1$ and $C Y C B 2 ; 4$ cyclins genes. In roots, expression levels of $C D K s$ as well as $C Y C s$ genes stayed unchanged. Therefore, it can be postulated that the observed inhibition of Arabidopsis shoot development and elongation is, at least partially, due to downregulation of the core cell-cycle genes in shoots. However, the involvement of core cell cycle genes in inhibition of lateral root formation and root elongation could only be elucidated after examining cell cycle gene expression at time points after the onset of the treatment with the root exudates. We cannot rule out that factors different from those included in cell cycle regulation, e.g. giberelin metabolism (Gou et al. 2010) or polar auxin transport (Brown et al. 2001; Peer et al. 2004), are much more engaged in the root growth retardation, which is the object of our further research aimed to elucidate the background of the allelopathy in apple. In addition, allelopathic effect demonstrated on arabidopsis nominated the apple in vitro culture products as putative eco-friendly bio-herbicides for weed control in crop fields (Jabran et al. 2015). Therefore, the apple hairy root cultures could be used as bioreactors for accumulation of secondary metabolites with bio-herbicidal properties, enabling at the same time their enhanced production by elicitation (Ramirez-Estrada et al. 2016). 


\section{Conclusion}

The present work describes successful genetic transformation of four apple cultivars Melrose, Golden Delicious, Čadel and Gloster by A. rhizogenes strain 15834, and the first in vitro establishment of apple hairy root cultures. UHPLC/(+/-)HESI-MS/MS analysis of phenolic compound content in untransformed and hairy root tissues revealed high similarity, confirming that genetic transformation by agrobacterium did not disturb the production and profile of phenolic secondary metabolites in apple. Chlorogenic and caffeic acid, as well as dihydrochalcones phloridzin and phloretin were annotated as putative allelochemicals in hairy root growth medium that caused a significant retardation in the development and growth of $A$. thaliana seedling used as a test plant. Down-regulation of the core cell-cycle genes CDKA1;1, CDKB2;1, CYCA3;1 and $C Y C B 2 ; 4$ in shoots is, at least partially, responsible for such effect. As an aseptic system free from microbial activities as well as other interactions commonly present in natural habitats, the hairy root culture can serve as a valuable tool for studying the allelopathic potential of apple. Since this system mimicked natural dynamics in metabolism of dihydrochalcones and other phenolics in apple, it could also be suitable for functional characterization of genes involved in biosynthesis of these compounds, as well as genetic manipulations to improve apple allelopathic attributes.

\section{Conflict of interest}

We declare that we have no conflict of interest.

\section{Funding}

The authors would like to express their gratitude to the Ministry of Education, Science and Technological Development of the Republic of Serbia for financial support through Project No. 173015. 


\section{References}

Ahmed MS, Ainley K, Parish JH, Had SM (1994) Free radical-induced fragmentation of proteins by quercetin. Carcinogenesis 15:1627-1630.

Alpizar E, Dechamp E, Lapeyre-Montes F, Guilhaumon C, Bertrand B, Jourdan C, Lashermes P, Etienne H (2008) Agrobacterium rhizogenes-transformed roots of Coffee (Coffea arabica): conditions for long-term proliferation, and morphological and molecular characterization. Ann Bot 101:929-940.

Amb MK, Ahluwalia AS (2016) Allelopathy: Potential role to achieve new milestones in rice cultivation. Rice Sci 23:165-183.

Awad MA, de Jager A, van Westing LM (2000) Flavonoid and chlorogenic acid levels in apple fruit: characterisation of variation. Sci Hortic 83:249-263.

Bai R, Zhao X, Ma F, Li C (2009) Identification and bioassay of allelopathic substances from the root exudates of Malus prunifolia. Allelopath J 23:477-484.

Bais HP, Weir TL, Perry LG, Gilroy S, Vivanco JM (2006) The role of root exudates in rhizosphere interactions with plants and other organisms. Annu Rev Plant Biol 57:233-266.

Bais HP, Vepachedu R, Gilroy S, Callaway RM, Vivanco JM (2003) Allelopathy and exotic plant invasion: from molecules and genes to species interactions. Science 301:1377-1380.

Batish DR, Singh HP, Kaur S, Kohli RK, Yadav SS (2008) Caffeic acid affects early growth, and morphogenetic response of hypocotyl cuttings of mung bean (Phaseolus aureus). J Plant Physiol 165:297-305.

Batra J, Dutta A, Singh D, Kumar S, Sen J (2004) Growth and terpenoid indole alkaloid production in Catharanthus roseus hairy root clones in relation to left- and right-termini-linked Ri T-DNA gene integration. Plant Cell Rep 23:148-154.

Baumann K, De Paolis A, Costantino P, Gualberti G (1999) The DNA binding site of the Dof protein NtBBF1 is essential for tissue-specific and auxin-regulated expression of the rolB oncogene in plants. Plant Cell 11:323-334.

Bogdanović MD, Todorović SI, Banjanac T, Dragićević MB, Verstappen FWA, Bouwmeester HJ, Simonović AD (2014) Production of guaianolides in Agrobacterium rhizogenes - transformed chicory regenerants flowering in vitro. Ind Crops Prod 60:52-59.

Bonhomme V, Laurain-Mattar D, Fliniaux MA (2000) Effects of the rol C gene on hairy root: induction development and tropane alkaloid production by Atropa belladonna. J Nat Prod $63: 1249-1252$.

Börner H (1959) The excretion of phlorizin from apple root residues. Contrib Boyce Thompson Inst 20:39-56.

Bourgaud F, Gravot A, Milesi S, Gontier E (2001) Production of plant secondary metabolites: a historical perspective. Plant Sci 161:839-851.

Bratton SP (1976) Resource division in an understory herb community: responses to temporal and 
microtopographic gradients. Am Nat 110:679-693.

Brown DE, Rashotte AM, Murphy AS, Normanly J, Tague BW, Peer WA, Taiz L, Muday GK (2001) Flavonoids act as negative regulators of auxin transport in vivo in Arabidopsis. Plant Physiol 126:524-535.

Chatterjee AK, Gibbins LN (1969) Metabolism of phloridzin by Erwinia herbicola: nature of the degradation products, and the purification and properties of phloretin hydrolase. $\mathrm{J}$ Bacteriol 100:594-600.

Chaudhuri KN, Ghosh B, Tepfer D, Jha S (2005) Genetic transformation of Tylophora indica with Agrobacterium rhizogenes A4: growth and tylophorine productivity in different transformed root clones. Plant Cell Rep 24:25-35.

Chou C-H, Leu L-L (1992) Allelopathic substances and interactions of Delonix regia (Boj) Raf. J Chem Ecol 18:2285-2303.

Christey MC (2001) Use of ri-mediated transformation for production of transgenic plants. Vitr Cell Dev Biol - Plant 37:687-700.

Czjzek M, Cicek M, Zamboni V, Bevan DR, Henrissat B, Esen A (2000) The mechanism of substrate (aglycone) specificity in beta -glucosidases is revealed by crystal structures of mutant maize beta -glucosidase -DIMBOA, -DIMBOAGlc, and -dhurrin complexes. Proc Natl Acad Sci U S A 97:13555-13560.

Dmitrović S, Simonović A, Mitić N, Savić J, Cingel A, Filipović B, Ninković S (2015) Hairy root exudates of allelopathic weed Chenopodium murale L. induce oxidative stress and downregulate core cell cycle genes in Arabidopsis and wheat seedlings. Plant Growth Regul 75:365382.

Einhellig FA (2004) Mode of allelochemical action of phenolic compounds. In: Macías FA, Galindo JCG, Molinillo J M G, Cutler H G (eds) Allelopathy: Chemistry and mode of action of allelochemicals. CRC Press, Florida, pp 217-238.

Fründt C, Meyer AD, Ichikawa T MF (1998) A tobacco homologue of the Ri-plasmid orf13 gene causes cell proliferation in carrot root discs. Mol Gen Genet MGG 259:559-568.

Fu X, Harberd NP (2003) Auxin promotes Arabidopsis root growth by modulating gibberellin response. Nature 421:740-743.

Gamborg OL, Miller RA, Ojima K (1968) Nutrient requirements of suspension cultures of soybean root cells. Exp Cell Res 50:151-158.

Gašić K, Hernandez A, Korban SS (2004) RNA extraction from different apple tissues rich in polyphenols and polysaccharides for cDNA library construction. Plant Molecular Biology Reporter 22: 437-437.

Garg N, Garg OP (1989) Effect of exogenous treatment with some phenolic compounds on nitrogen fixation, growth, and yield in Cicer arietinum L.(chickpea). Curr Sci 58:31-32.

Gosch C, Halbwirth H, Stich K (2010) Phloridzin: Biosynthesis, distribution and physiological relevance in plants. Phytochemistry 71:838-843. 
Gou J, Strauss SH, Tsai CJ, Fang K, Chen Y, Jiang X, Busov VB (2010) Gibberellins regulate lateral root formation in Populus through interactions with auxin and other hormones. Plant Cell 22:623-639.

Gutierrez-Pesce P, Taylor K, Muleo R, Rugini E (1998) Somatic embryogenesis and shoot regeneration from transgenic roots of the cherry rootstock Colt (Prunus avium $\times$. pseudocerasus) mediated by pRi 1855 T-DNA of Agrobacterium rhizogenes. Plant Cell Rep 17:574-580.

Günl M, Neumetzler L, Kraemer F, de Souza A, Schultink A, Pena M, York WS, Pauly M (2011) AXY8 encodes an $\alpha$-fucosidase, underscoring the importance of apoplastic metabolism on the fine structure of Arabidopsis cell wall polysaccharides. Plant Cell 23:4025-4040.

Heisey RM (1990) Allelopathic and herbicidal effects of extracts from tree of heaven (Ailanthus altissima). Am J Bot 77:662-670.

Hoffmann T, Friedlhuber R, Steinhauser C, Tittel I, Skowranek K, Schwab W, Fischer TC (2011) Histochemical screening, metabolite profiling and expression analysis reveal Rosaceae roots as the site of flavan-3-ol biosynthesis. Plant Biol 14:33-40.

Hofmann A, Wittenmayer L, Arnold G, Schieber A, Merbach W (2009) Root exudation of phloridzin by apple seedlings (Malus x domestica Borkh.) with symptoms of apple replant disease. J Appl Bot Food Qual

Hrazdina G (2003) Response of scab-susceptible (McIntosh) and scab-resistant (Liberty) apple tissues to treatment with yeast extract and Venturia inaequalis. Phytochemistry 64:485-492.

Hunter MD, Hull LA (1993) Variation in concentrations of phloridzin and phloretin in apple foliage. Phytochemistry 34:1251-1254.

Inderjit (2005) Soil microorganisms: An important determinant of allelopathic activity. Plant Soil 274:227-236.

Jabran K, Mahajan G, Sardana V, Chauhan BS (2015) Allelopathy forweed control in agricultural systems. Crop Protection 72:57-65.

Jayasankar NP, Bandoni RJ, Towers GHN (1969) Fungal degradation of phloridzin. Phytochemistry 8:379-383.

Jones P, Vogt T (2001) Glycosyltransferases in secondary plant metabolism: tranquilizers and stimulant controllers. Planta 213:164-174.

Jugdé H, Nguy D, Moller I, Cooney JM, Atkinson RG (2008) Isolation and characterization of a novel glycosyltransferase that converts phloretin to phlorizin, a potent antioxidant in apple. FEBS J 275:3804-3814.

Jung K, Fujii Y, Yoshizaki S, Journal HK (2010) Evaluation of total allelopathic activity of heartseed walnut (Juglans ailanthifolia Carr.) and its potential to control black locust (Robinia pseudo-acacia L.). Allelopath J 26:243-251.

Kieffer M, Neve J, Kepinski S (2010) Defining auxin response contexts in plant development. Curr Opin Plant Biol 13:12-20. 
Kim YK, Li X, Xu H, Il Park N, Uddin MR, Pyon JY, Park SU (2009) Production of phenolic compounds in hairy root culture of tartary buckwheat (Fagopyrum tataricum Gaertn). J Crop Sci Biotechnol 12:53-57.

Kiselev KV, Dubrovina AS, Veselova MV, Bulgakov VP, Fedoreyev SA, Zhuravlev YN (2007) The rolB gene-induced overproduction of resveratrol in Vitis amurensis transformed cells. J Biotechnol 128:681-692.

Klein M, Burla B, Martinoia E (2006) The multidrug resistance-associated protein (MRP/ABCC) subfamily of ATP-binding cassette transporters in plants. FEBS Lett 580:1112-1122.

Kollárová K, Lińková D, Kákoniová D, Lux A (2004) Effect of auxins on Karwinskia humboldtiana root cultures. Plant Cell, Tissue and Organ culture 79:213-221.

Lambert C, Bianco J, Garello G, Le Page-Degivry M-T (1998) Alteration of hormonal levels and hormone sensitivity by Ri T-DNA-transformation of apple cuttings. J Plant Physiol 153:677683.

Lambert C, Tepfer D (1992) Use of Agrobacterium rhizogenes to create transgenic apple trees having an altered organogenic response to hormones. Theor Appl Genet 85:105-109.

Lee S, Cho S, Park M, Kim Y, Choi J, Park S (2007) Growth and rutin production in hairy root cultures of buckwheat ( Fagopyrum esculentum M.). Prep Biochem Biotechnol 37:239-246.

Lee J, Das A, Yamaguchi M, Hashimoto J, Tsutsumi N, Uchimiya H, Umeda M (2003) Cell cycle function of a rice B2-type cyclin interacting with a B-type cyclin-dependent kinase. Plant $\mathrm{J}$ $34: 417-425$.

Li Z-H, Wang Q, Ruan X, Pan C-D, Jiang D-A (2010) Phenolics and Plant Allelopathy. Molecules 15:8933-8952.

Linsmaier EM, Skoog F (1965) Organic growth factor requirements of Tobacco tissue cultures. Physiol Plant 18:100-127.

Liu C, Zhu J, Liu Z, Li L, Pan R, Jin L (2002) Exogenous auxin effects on growth and phenotype of normal and hairy roots of Pueraria lobata (Willd.) Ohwi. Plant Growth Regul 38:37-43.

Livak KJ, Schmittgen TD (2001) Analysis of relative gene expression data using real-time quantitative PCR and the 2- $\Delta \Delta C T$ Method. Methods 25:402-408.

Lloyd G and McCown B (1981) Commercially feasible micropropagation of mountain laurel, Kalsmia latifolia, by use of shoot tip culture. Proceedings of IPPS 30:421-427.

Łata B, Trampczynska A, Paczesna J (2009) Cultivar variation in apple peel and whole fruit phenolic composition. Sci Hortic 121:176-181.

Mahnkopp F, Simon M, Lehndorff E, Pätzold S, Wrede A, Winkelmann T (2018) Induction and diagnosis of apple replant disease (ARD): a matter of heterogeneous soil properties? Sci Hortic 241:167-177.

Matsumoto T, Yoshida D, Mizusaki S, Okamoto H (1977) Mutagenic activity of amino acid pyrolyzates in Salmonella typhimurium TA 98. Mutat Res 48:279-286. 
Menges M, De Jager SM, Gruissem W, Murray JAH (2005) Global analysis of the core cell cycle regulators of Arabidopsis identifies novel genes, reveals multiple and highly specific profiles of expression and provides a coherent model for plant cell cycle control. Plant J 41:546-566.

Meyer AD, Ichikawa T, Meins F (1995) Horizontal gene transfer: regulated expression of a tobacco homologue of the Agrobacterium rhizogenes rolC gene. MGG Mol Gen Genet 249:265-273.

Mikulic Petkovšek M, Stampar F, Veberic R (2009) Seasonal changes in phenolic compounds in the leaves of scab-resistant and susceptible apple cultivars. Can J Plant Sci 89:745-753.

Mikulic Petkovšek M, Stampar F, Veberic R (2008) Increased phenolic content in apple leaves infected with the apple scab pathogen. J Plant Pathol 90:49-55.

Mišić D, Šiler B, Gašić U, Avramov S, Živković S, Nestorović Živković J, Milutinović M, Tešić Ž (2015) Simultaneous UHPLC/DAD/(+/-)HESI-MS/MS analysis of phenolic acids and nepetalactones in methanol extracts of Nepeta species: a possible application in chemotaxonomic studies. Phytochem Anal 26:72-85.

Mitić N, Dmitrović S, Djordjević M, Zdravković-Korać S, Nikolić R, Raspor M, Djordjević T, Maksimović V, Živković S, Krstić-Milošević D, Stanišić M, Ninković S (2012) Use of Chenopodium murale L. transgenic hairy root in vitro culture system as a new tool for allelopathic assays. J Plant Physiol 169:1203-1211.

Molish H (1937) Der Einflus einer Pflanze auf die andere: Allelopathie. Gustav Fischer Verlag, Jena.

Murashige T, Skoog F (1962) A revised medium for rapid growth and bio assays with Tobacco tissue cultures. Physiol Plant 15:473-497.

Natsume H, Seto H, Ōtake N (1982) Studies on Apple canker disease. The necrotic toxins produced by Valsa ceratosperma. Agric Biol Chem 46:2101-2106.

Niakan M, Saberi K (2009) Effects of eucalyptus allelopathy on growth characters and antioxidant enzymes activity in Phalaris weed. Asian J Plant Sci 8:440.

Nicola L, Vrhovsek U, Evelyn S, Insam H, Pertot I (2017) Phlorizin released by apple root debris is related to apple replant disease. Phytopathol Mediterr 55:432-442.

Nilsson O, Olsson O (1997) Getting to the root: The role of the Agrobacterium rhizogenes rol genes in the formation of hairy roots. Physiol Plant 100:463-473.

Ninković S, Djordjević T, Vinterhalter B, Uzelac B, Cingel A, Savić J, Radović S (2010) Embryogenic responses of Beta vulgaris L. callus induced from transgenic hairy roots. Plant Cell, Tissue Organ Cult 103:81-91.

Nishida N, Tamotsu S, Nagata N, Saito C, Sakai A (2005) Allelopathic effects of volatile monoterpenoids produced by Salvia leucophylla: inhibition of cell proliferation and DNA synthesis in the root apical meristem of Brassica campestris seedlings. J Chem Ecol 31:11871203.

Palik B, Engstrom R. (1999) Species composition. In: Hunter M. (ed) Maintaining biodiversity in 
forest ecosystems. Cambridge University Press, Cambridge, pp 65-94.

Park S-U, Facchini PJ (2000) Agrobacterium rhizogenes-mediated transformation of opium poppy, Papaver somniferum L., and California poppy, Eschscholzia californica Cham., root cultures. J Exp Bot 51:1005-1016.

Patena L, Sutter EG, Dandekar AM (1988) Root induction by Agrobacterium rhizogenes in a difficult-to-root woody species. Acta Hortic:324-329.

Patterson DT (1981) Effects of allelopathic chemicals on growth and physiological responses of soybean (Glycine max). Weed Sci 29:53-59.

Pawlicki-Jullian N, Sedira M, Welander M (2002) The use of Agrobacterium rhizogenes transformed roots to obtain transgenic shoots of the apple rootstock Jork 9. Plant Cell Tissue Organ Cult 70:163-171.

Peer WA, Bandyopadhyay A, Blakeslee JJ, Makam SN, Chen RJ, Masson PH, Murphy AS (2004) Variation in expression and protein localization of the PIN family of auxin efflux facilitator proteins in flavonoid mutants with altered auxin transport in Arabidopsis thaliana. Plant Cell 16:1898-1911.

Pennacchio M, Jefferson L V., Havens K (2005) Arabidopsis thaliana: a new test species for phytotoxic bioassays. J Chem Ecol 31:1877-1885.

Péret B, De Rybel B, Casimiro I, Benková E, Swarup R, Laplaze L, Beeckman T, Bennett MJ (2009) Arabidopsis lateral root development: an emerging story. Trends Plant Sci 14:399-408.

Petri C, Burgos L (2005) Transformation of fruit trees. Useful breeding tool or continued future prospect? Transgenic Res 14:15-26.

Pontais I, Treutter D, Paulin J-P, Brisset M-N (2008) Erwinia amylovora modifies phenolic profiles of susceptible and resistant apple through its type III secretion system. Physiol Plant 132:262271.

Ramirez-Estrada K, Vidal-Limon H, Hidalgo D, Moyano E, Golenioswki M, Cusidó RM, Palazon J (2016) Elicitation, an effective strategy for the biotechnological production of bioactive highadded value compounds in plant cell factories. Molecules 21:1-24.

Reigosa MJ, Pazos-Malvido E (2007) Phytotoxic effects of 21 plant secondary metabolites on Arabidopsis thaliana germination and root growth. J Chem Ecol 33:1456-1466.

Rueff J, Gaspar J, Laires A (1995) Structural requirements for mutagenicity of flavonoids upon nitrosation. A structure - activity study. Mutagenesis 10:325-328.

Rugini E, Mariotti D (1992) Agrobacterium rhizogenes T-DNA genes and rooting in woody species. Acta Hortic:301-308.

Sanchez-Moreiras AM, de la Pena TC, Reigosa MJ (2008) The natural compound benzoxazolin-2 $(3 \mathrm{H})$-one selectively retards cell cycle in lettuce root meristems. Phytochemistry 69:21722179.

Shen WH, Petit A, Guern J, Tempé J (1988) Hairy roots are more sensitive to auxin than normal 
roots. Proc Natl Acad Sci U S A 85:3417-3421.

Shkryl YN, Veremeichik GN, Bulgakov VP, Tchernoded GK, Mischenko NP, Fedoreyev SA, Zhuravlev YN (2008) Individual and combined effects of the rolA,B, and $\mathrm{C}$ genes on anthraquinone production in Rubia cordifolia transformed calli. Biotechnol Bioeng 100:118125.

Sirikantaramas S, Yamazaki M, Saito K (2008) Mechanisms of resistance to self-produced toxic secondary metabolites in plants. Phytochem Rev 7:467-477.

Smigocki AC, Ivic-Haymes S, Li H, Savić J (2013) Pest Protection Conferred by a Beta vulgaris Serine Proteinase Inhibitor Gene Doucet D (ed). PLoS One 8:e57303.

Soltys D, Rudzińska-Langwald A, Kurek W, Gniazdowska A, Sliwinska E, Bogatek R (2011) Cyanamide mode of action during inhibition of onion (Allium cepa L.) root growth involves disturbances in cell division and cytoskeleton formation. Planta 234:609-621.

Souto XC, Gonzales L, Reigosa MJ (1994) Comparative analysis of allelopathic effects produced by four forestry species during decomposition process in their soils in Galicia (NW Spain). J Chem Ecol 20:3005-3015.

Su Y-H, Liu Y-B, Zhang X-S (2011) Auxin-cytokinin interaction regulates meristem development. Mol Plant 4:616-625.

Sutter EG, Luza J (1993) Development anatomy of roots induced by Agrobacterium rhizogenes in Malus pumila 'M.26' shoots grown in vitro. Int J Plant Sci 154:59-67.

Tada H, Shimomura K, Ishimaru K (1995) Polyacetylenes in Platycodon grandiflorum hairy root and Campanulaceous plants. J Plant Physiol 145:7-10.

Tanaka N, Yamakawa M, Yamashita I (1998) Characterization of transcription of genes involved in hairy root induction on pRi1724 core-T-DNA in two Ajuga reptans hairy root lines. Plant Sci 137:95-105.

Taneja J, Jaggi M, Wankhede DP, Sinha AK (2010) Effect of loss of T-DNA genes on MIA biosynthetic pathway gene regulation and alkaloid accumulation in Catharanthus roseus hairy roots. Plant Cell Rep 29:1119-1129.

Teale WD, Paponov IA, Palme K (2006) Auxin in action: signalling, transport and the cont of plant growth and development. Nat Rev Mol Cell Biol 7:847-859.

Tepfer D (1983) The biology of genetic transformation of higher plants by Agrobacterium rhizogenes. In: Pühler A (ed) Molecular genetics of the bacteria-plant interaction. SpringerVerlag, Berlin, Heidelberg, pp 248-258.

Tepfer M, Casse-Delbart F (1987) Agrobacterium rhizogenes as a vector for transforming higher plants. Microbiol Sci 4:24-28.

Tiwari RK, Trivedi M, Guang ZC, Guo G-Q, Zheng G-C (2007) Genetic transformation of Gentiana macrophylla with Agrobacterium rhizogenes: growth and production of secoiridoid glucoside gentiopicroside in transformed hairy root cultures. Plant Cell Rep 26:199-210. 
Treutter D (2001) Biosynthesis of phenolic compounds and its regulation in apple. Plant Growth Regul 34:71-89.

Triplett BA, Moss SC, Bland JM, Dowd MK (2008) Induction of hairy root cultures from Gossypium hirsutum and Gossypium barbadense to produce gossypol and related compounds. Vitr Cell Dev Biol - Plant 44:508-517.

Van Leene J, Hollunder J, Eeckhout D, Persiau G, De Slijke E Van, Stals H, Van Isterdael G, Verkest A, Neirynck S, Buffel Y, De Bodt S, Maere S, Laukens K, Pharazyn A, Ferreira PC, Eloy N, Renne C, Meyer C, Faure J-D, Steinbrenner J, Beynon J, Larkin JC, Van De Peer Y, Hilson P, Kuiper M, De Veylder L, Van Onckelen H, Inzé D, Witters E, De Jaeger G (2010) Targeted interactomics reveals a complex core cell cycle machinery in Arabidopsis thaliana. Mol Syst Biol 6:397.

Vandepoele K, Raes J, De Veylder L, Rouzé P, Rombauts S, Inzé D (2002) Genome-wide analysis of core cell cycle genes in Arabidopsis. Plant Cell 14:903-916.

Velasco R, Zharkikh A, Affourtit J, Dhingra A, Cestaro A, Kalyanaraman A, Fontana P, Bhatnagar SK, Troggio M, Pruss D, Salvi S, Pindo M, Baldi P, Castelletti S, Cavaiuolo M, Coppola G, Costa F, Cova V, Dal Ri A, Goremykin V, Komjanc M, Longhi S, Magnago P, Malacarne G, Malnoy M, Micheletti D, Moretto M, Perazzolli M, Si-Ammour A, Vezzulli S, Zini E, Eldredge G, Fitzgerald LM, Gutin N, Lanchbury J, Macalma T, Mitchell JT, Reid J, Wardell B, Kodira C, Chen Z, Desany B, Niazi F, Palmer M, Koepke T, Jiwan D, Schaeffer S, Krishnan V, Wu C, Chu VT, King ST, Vick J, Tao Q, Mraz A, Stormo A, Stormo K, Bogden R, Ederle D, Stella A, Vecchietti A, Kater MM, Masiero S, Lasserre P, Lespinasse Y, Allan AC, Bus V, Chagné D, Crowhurst RN, Gleave AP, Lavezzo E, Fawcett JA, Proost S, Rouzé P, Sterck L, Toppo S, Lazzari B, Hellens RP, Durel C-E, Gutin A, Bumgarner RE, Gardiner SE, Skolnick M, Egholm M, Van de Peer Y, Salamini F, Viola R (2010) The genome of the domesticated apple (Malus $\times$ domestica Borkh.). Nat Genet 42:833-839.

Vervliet G, Holsters M, Teuchy H, Van Montagu M, Schell J (1975) Characterization of different plaque-forming and defective temperate phages in Agrobacterium strains. J Gen Virol 26:3348.

Vinterhalter B, Ninković S, Cingel A, Vinterhalter D (2006) Shoot and root culture of Hypericum perforatum L. transformed with Agrobacterium rhizogenes A4M70GUS. Biol Plant 50:767770.

Warzecha H, Obitz P, Stöckigt J (1999) Purification, partial amino acid sequence and structure of the product of raucaffricine-O- $\beta$-d-glucosidase from plant cell cultures of Rauwolfia serpentina. Phytochemistry 50:1099-1109.

Washida D, Shimomura K, Nakajima Y, Takido M, Kitanaka S (1998) Ginsenosides in hairy roots of a panax hybrid. Phytochemistry 49:2331-2335.

Weiß S, Liu B, Reckwell D, Beerhues L, Winkelmann T (2017) Impaired defense reactions in apple replant disease-affected roots of Malus domestica 'M26'. Tree Physiol 37:1672-1685.

White FF, Garfinkel DJ, Huffman GA, Gordon MP, Nester EW (1983) Sequences homologous to Agrobacterium rhizogenes T-DNA in the genomes of uninfected plants. Nature 301:348-350. 
Willis RJ (2000) Juglans spp., juglone and allelopathy. Allelopathy J 7:1-55.

Wu J, Wang Y, Zhang L-X, Zhang X-Z, Kong J, Lu J, Han Z-H (2012) High-efficiency regeneration of Agrobacterium rhizogenes-induced hairy root in apple rootstock Malus baccata (L.) Borkh. Plant Cell, Tissue Organ Cult 111:183-189.

Yamashita H, Daimon H, Akasaka-Kennedy Y, Masuda T (2004) Plant regeneration from hairy roots of apple rootstock, Malus prunifolia Borkh. var. ringo Asami, Strain Nagano No.1, transformed by Agrobacterium rhizogenes. J Japanese Soc Hortic Sci 73:505-510.

Yin C, Duan Y, Xiang L, Wang G, Zhang X, Shen X, Chen X, Zhang M, Mao Z (2018) Effects of phloridzin, phloretin and benzoic acid at the concentrations measured in soil on the root proteome of Malus hupehensis Rehd seedlings. Sci Hortic 228:10-17.

Yin C, Xiang L, Wang G, Wang Y, Shen X, Chen X, Mao Z (2016) How to plant apple trees to reduce replant disease in apple orchard: a study on the phenolic acid of the replanted apple orchard. PLoS One 11:e0167347.

Zhang Y, Gu M, Shi K, Zhou YH, Yu JQ (2010) Effects of aqueous root extracts and hydrophobic root exudates of cucumber (Cucumis sativus L.) on nuclei DNA content and expression of cell cycle-related genes in cucumber radicles. Plant Soil 327:455-463.

Zhang, Hai, Jin-Ming Gao, Wei-Tao Liu, Jing-Cheng Tang, Xing-Chang Zhang, Zhen-Guo Jin, Yao-Ping Xu and M-AS (2008) Allelopathic substances from walnut (Juglans regia L.) leaves. Allelopath J 21:425-431.

Zhang J-H, Mao Z-Q, Wang L-Q, Shu H-R (2007a) Bioassay and identification of root exudates of three fruit tree species. J Integr Plant Biol 49:257-261.

Zhang XZ, Zhao YB, Li CM, Chen DM, Wang GP, Chang RF, Shu HR (2007b) Potential polyphenol markers of phase change in apple (Malus domestica). J Plant Physiol 164:574-580. 


\section{Figure legends}

Figure 1. Hairy roots emerging from wound sites on apple stem.

Figure 2. Regenerated apple hairy roots seven weeks after shoot inoculation with $A$. rhizogenes strain 15834. Hairy roots emerging from the cut-edge of apple shoot (red arrow), 15 mm upstream the cut-edge (black arrow) and on the leaf surface (blue arrow) (A); Agravitopic growth of regenerated hairy root (B); Hairy roots fused together at their bases forming irregular shape structure (arrow) (C); Light pink (D) or yellow (E) coloration of hairy roots; Callusing surface of hairy roots $(\mathrm{F})$.

Figure 3. Morphology of transformed and untransformed apple root lines. Transgenic fast growing line GD12 (A) and GD1 (B); moderately growing line GD11(C); and a poor growing line GD3 (D). Rooted Golden Delicious control shoot (E); Control root line supplemented with the auxin $\operatorname{IBA}(\mathrm{E})$.

Figure 4. Influence of mineral solutions (A) and auxins in $1 / 2 \mathrm{MS}(\mathrm{B})$ on biomass production in hairy root line GD12 at six weeks of cultivation. Values are means of three replicates per each treatment repeated twice $(n=6)$. Treatments denoted by the same letter are not significantly different $(\mathrm{P} \leq 0.05)$ per Fisher's least significant difference (LSD) test. MS = Murashige and Skoog mineral solution (Murashige and Skoog, 1962), 1/2MS = half strength MS, B5 = Gamborg mineral solution (Gamborg er al., 1968), 1/2B5 = half strength B5, WPM = Woody plant medium (Lloyd and McCown, 1980), 1/2WPM = half strength WPM, IBA $=$ indole-3-butyric acid, NAA $=\alpha$ naphthaleneacetic acid.

Figure 5. Effect of apple hairy root exudates on A. thaliana growth at 10 days of treatment. Control seedlings in $1 / 2 \mathrm{MS}$ medium (A), Arabidopsis seedlings treated with apple hairy root exudates in $1 / 2 \mathrm{MS}(\mathrm{B}) ; \mathrm{Bar}=5 \mathrm{~mm}$. 
Figure 6. Effect of apple hairy root exudates on A. thaliana seedling lateral root number (A), root length (B) and shoot length (C) at five and 10 days of treatment as compared to untreated control. Values are presented as means $( \pm$ SE) of three replicates with 10 explants per each treatment repeated twice $(\mathrm{n}=60)$. Asterisks indicate statistically significant difference at $\mathrm{P}<0.05$ based on $t$ test, while numbers above the bars indicate the percentage of inhibition (-).

Figure 7. Expression levels of $C D K A 1 ; 1, C D K B 2 ; 1, C Y C A 3 ; 1$ and $C Y C B 2 ; 4$ genes in $A$. thaliana shoots and roots at 10 days of treatment with apple hairy root exudates. Data are presented as means of three biological replicates with standard error bars. Expression levels were calculated relative to an expression of related non-treated control according to the $\Delta \Delta \mathrm{Ct}$ method and presented as $\log 2$ transformation of fold changes.

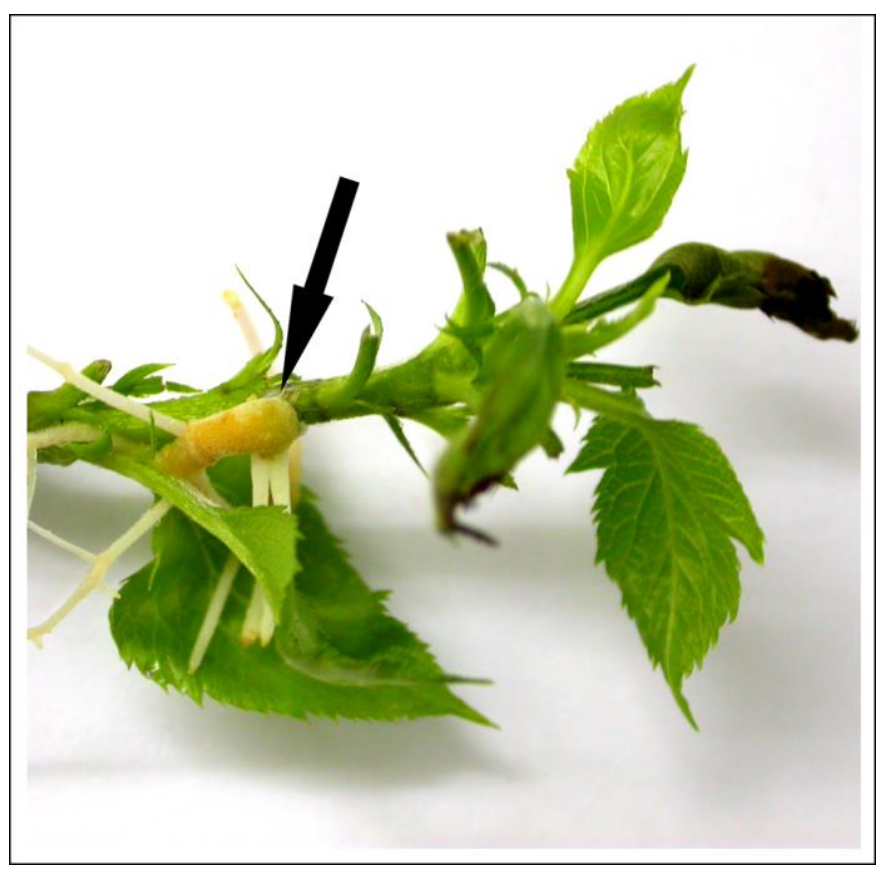

Figure 1. 


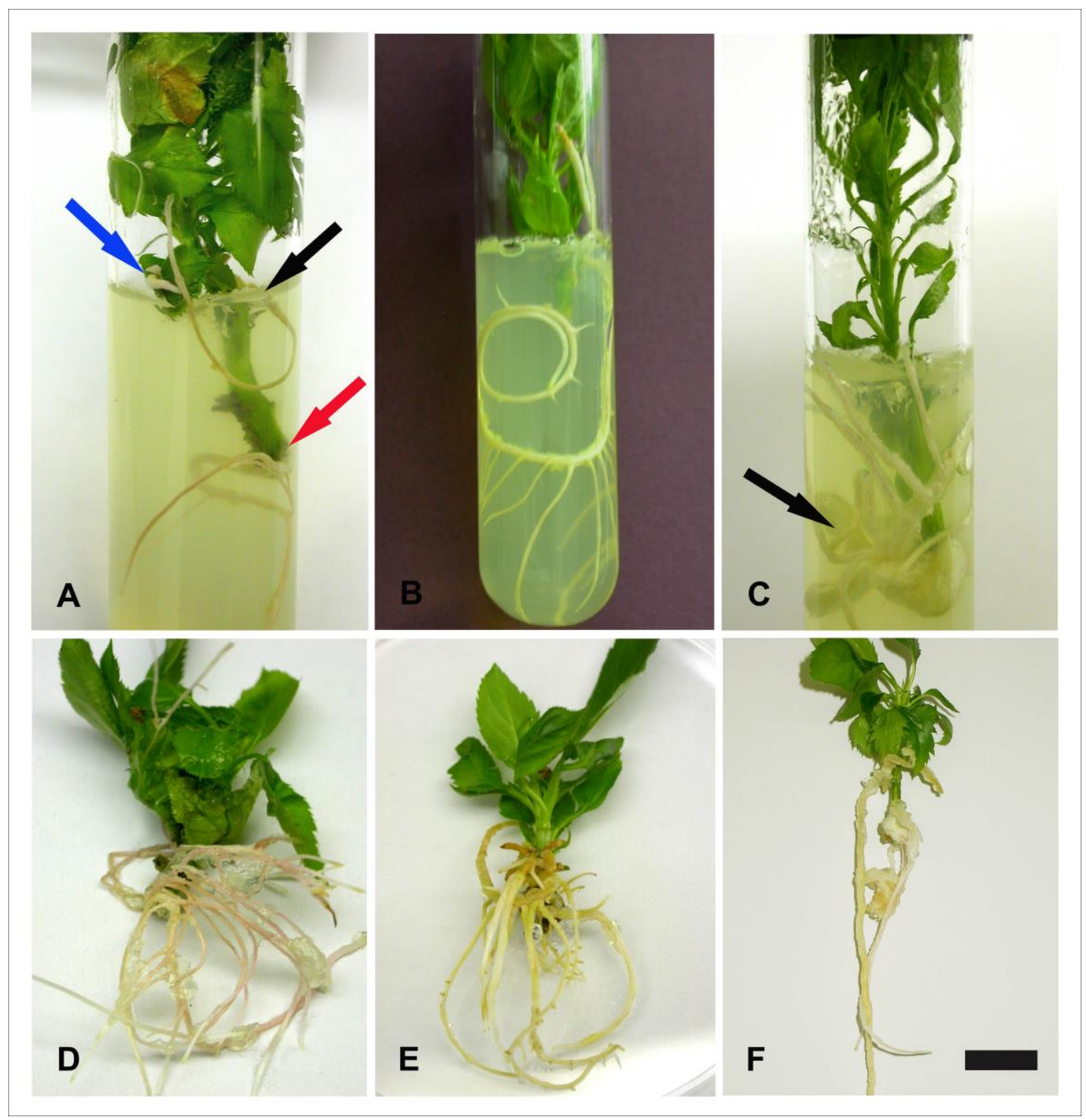

Figure 2. 


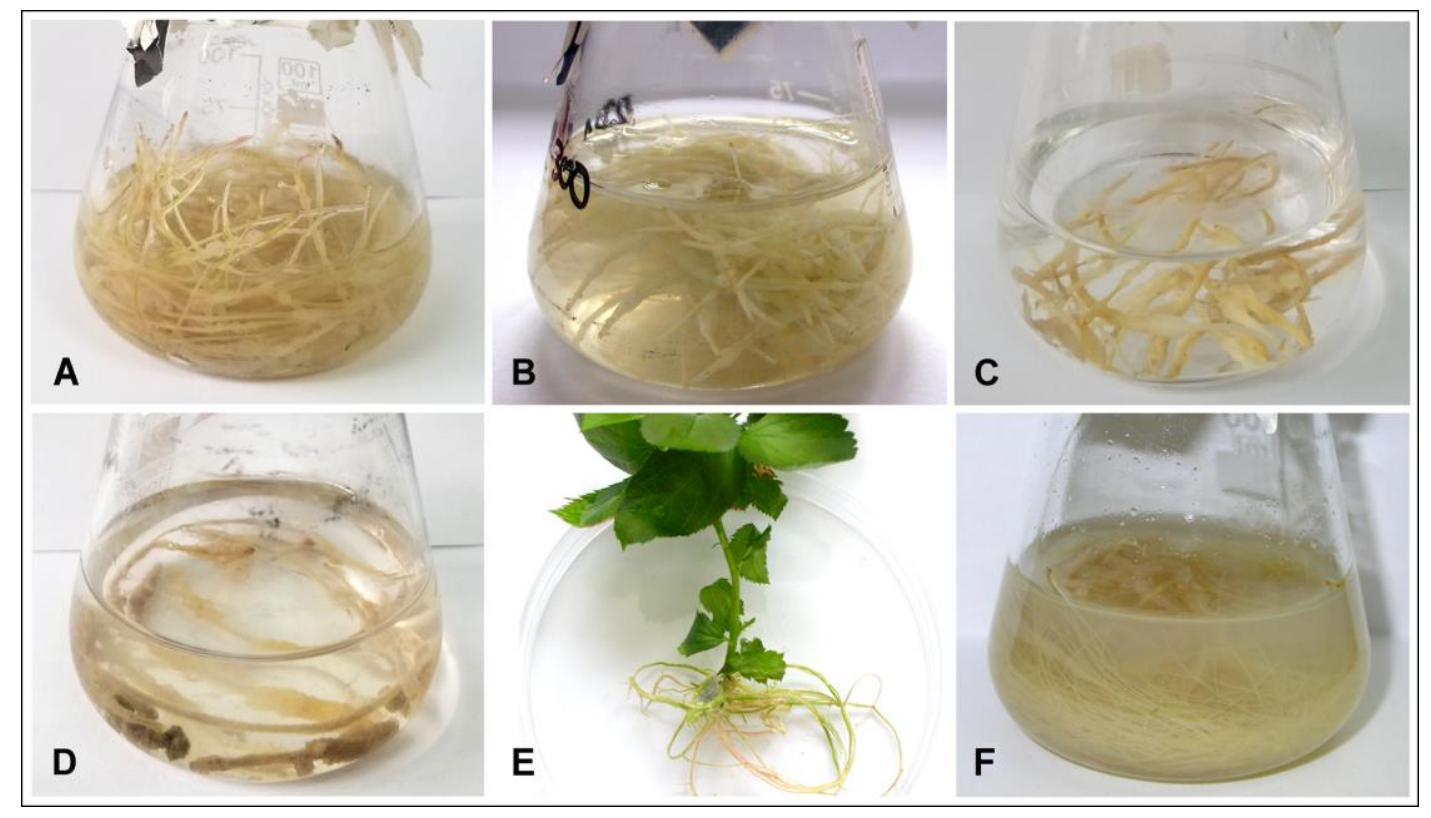

Figure 3. 


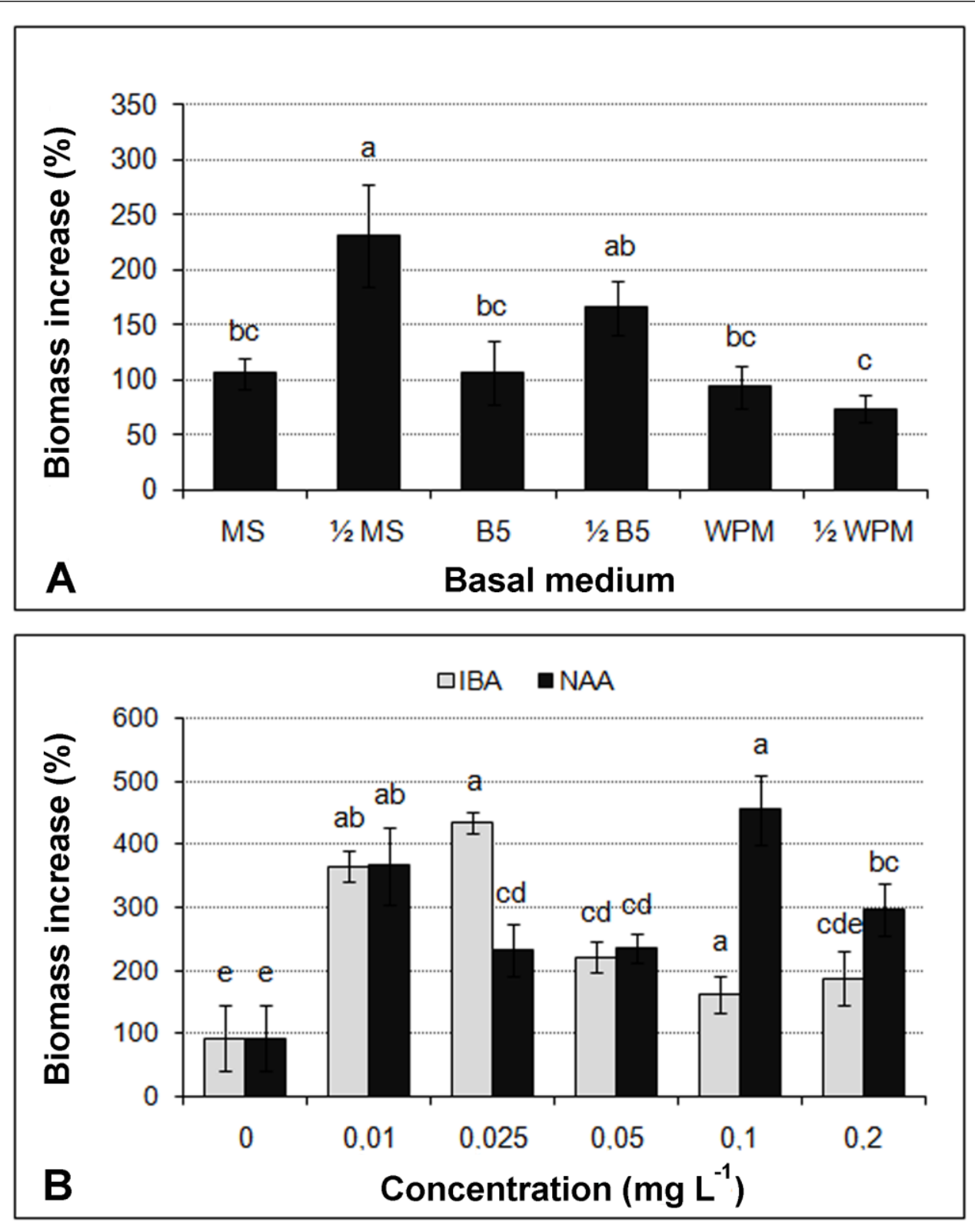

Figure 4. 


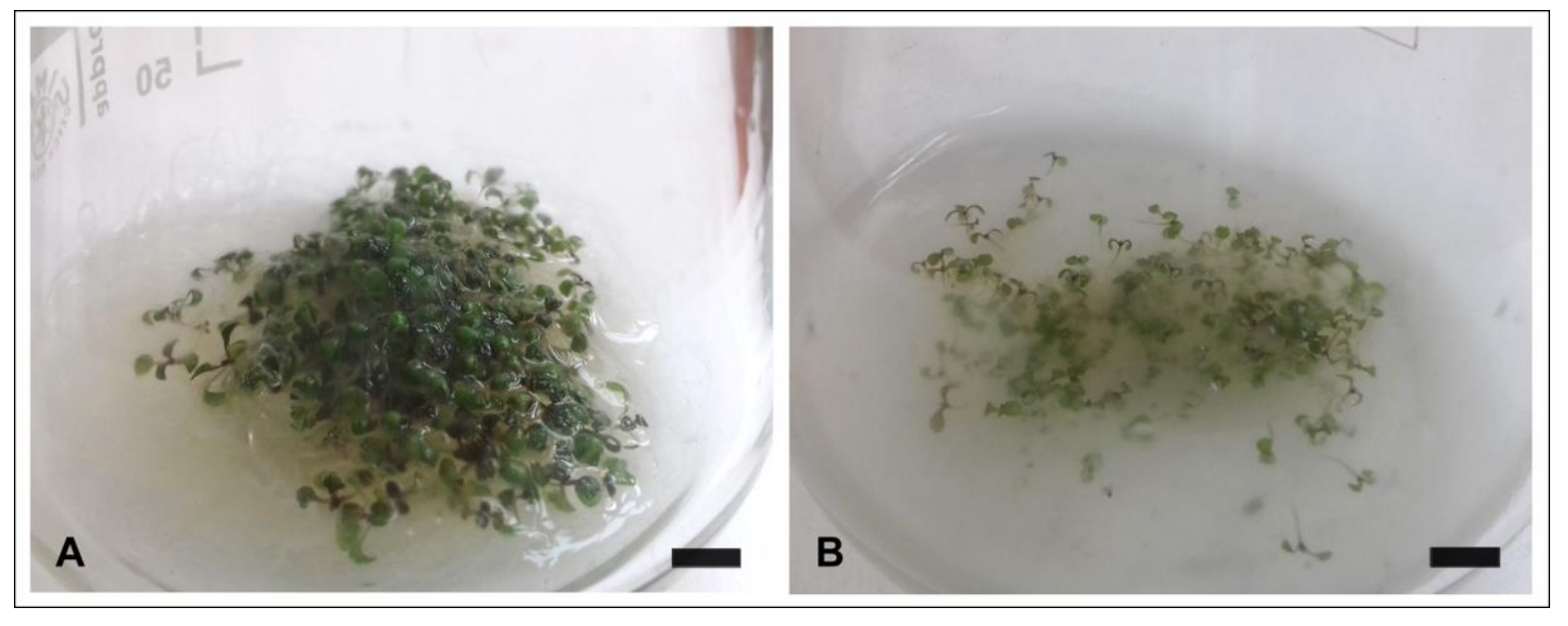

Figure 5. 


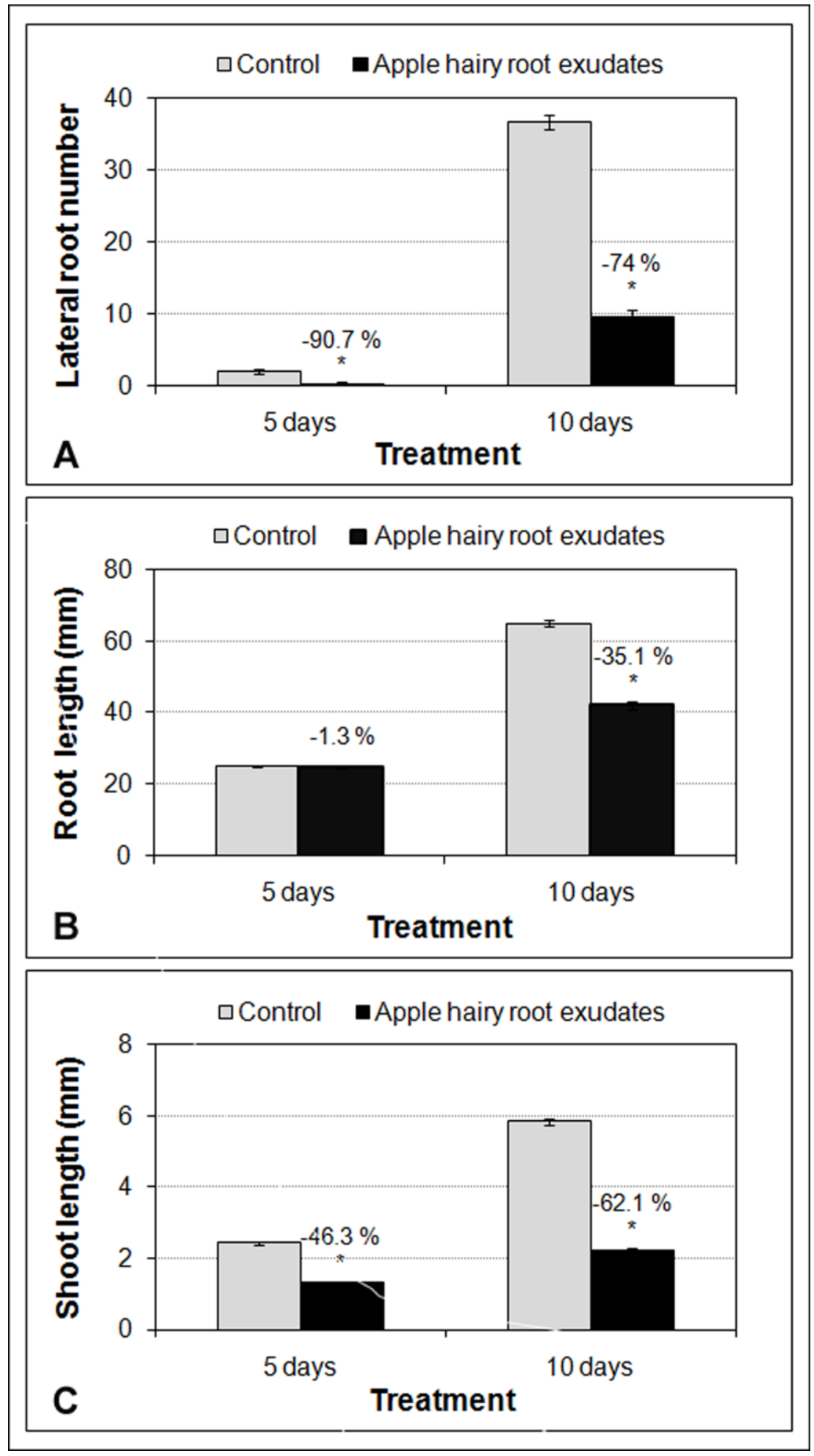

Figure 6. 

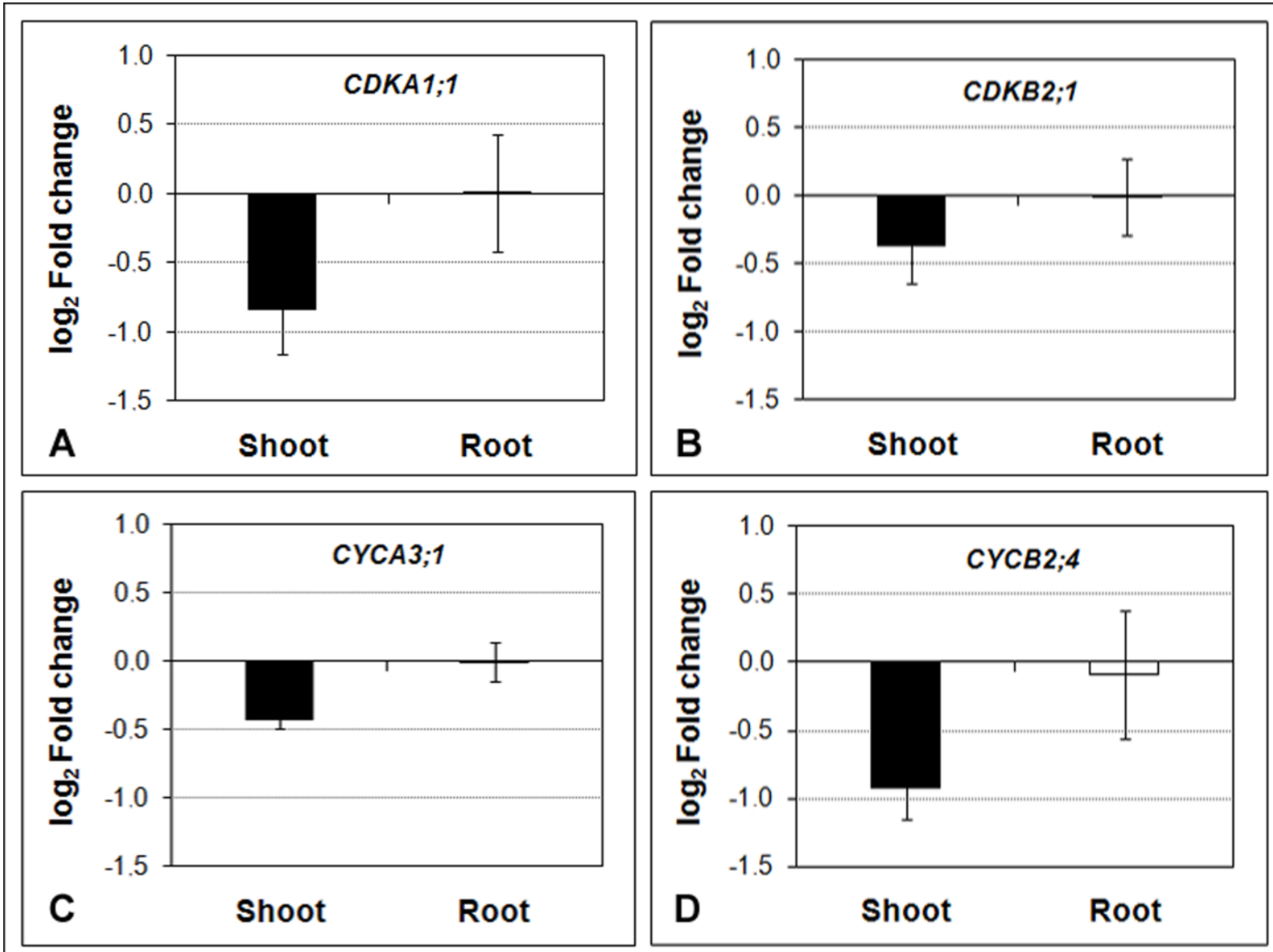

Figure 7. 
Table 1. List of primers used for RT-PCR analyses of transgenes in A. rhizogenes putatively transformed apple hairy roots.

\begin{tabular}{|c|c|c|}
\hline Gene name & $\begin{array}{l}\text { Sequence } \\
\left(5^{\prime}-3 \text { ') }\right.\end{array}$ & $\begin{array}{l}\text { Amplified product } \\
\text { size (bp) }\end{array}$ \\
\hline rolA & $\begin{array}{l}\text { F: GTTAGGCGTGCAAAGGCCAAG } \\
\text { R: CGTATTAATCCCGTAGGTC }\end{array}$ & 203 \\
\hline rolB & $\begin{array}{l}\text { F: AAAGTCTGCTATCATCCTCCTATG } \\
\text { R: AAAGAAGGTGCAAGCTACCTCTCT }\end{array}$ & 348 \\
\hline rolc & $\begin{array}{l}\text { F: TACGTCGACTGCCCGACGATGATG } \\
\text { R: AAACTTGCACTCGCCATGCCTCAC }\end{array}$ & 342 \\
\hline rolD & $\begin{array}{l}\text { F: CCTTACGAATTCTCTTAGCGGCACC } \\
\text { R: GAGGTACACTGGACTGAATCTGCAC }\end{array}$ & 477 \\
\hline auxl & $\begin{array}{l}\text { F: CATAGGATCGCCTCACAGGT } \\
\text { R: CGTTGCTTGATGTCAGGAGA }\end{array}$ & 198 \\
\hline $\operatorname{aux} 2$ & $\begin{array}{l}\text { F: AACGATAATAGCCCGCTGTG } \\
\text { R: CGTCTTGGGTTTGTGGTTCT }\end{array}$ & 217 \\
\hline virD1 & $\begin{array}{l}\text { F: ATGTCGCAAGGCAGTAAG } \\
\text { R: CAAGGAGTCTTTCAGCATG }\end{array}$ & 441 \\
\hline MdActin & $\begin{array}{l}\text { F: ATTGGAATGGAAGCTGCTGG } \\
\text { R: CAATGGATGGACCTGACTCG' }\end{array}$ & 310 \\
\hline
\end{tabular}


Table 2. List of primers used for qPCR analyses of cell cycle related genes in A. thaliana.

\begin{tabular}{|c|c|c|c|}
\hline Gene name & GenBank accession number & $\begin{array}{l}\text { Sequence } \\
\left(5^{\prime}-3^{\prime}\right)\end{array}$ & $\begin{array}{c}\text { Amplified } \\
\text { product size (bp) }\end{array}$ \\
\hline$C D K A 1 ; 1$ & NM_114734 & $\begin{array}{l}\text { F: CCGTACGAGGATACATGGCG } \\
\text { R: GGAGATCGACTCCATCGGGA }\end{array}$ & 124 \\
\hline$C D K B 2 ; 1$ & NM_106304 & $\begin{array}{l}\text { F: GTACGAGCCAGCGAAACGAA } \\
\text { R: GCAGCACACTAGAGATATGCTTGA }\end{array}$ & 170 \\
\hline CYCA3;1 & NM_123674.2 & $\begin{array}{l}\text { F: GCGGGTGATTTGAAAGAATGTGTG } \\
\text { R: GGTGATACAGGCATTGTCGCT }\end{array}$ & 134 \\
\hline CYCB2;4 & NM_106281 & $\begin{array}{l}\text { F: GCATCGGCGATCTACACTGC } \\
\text { R: CCCTGCCTTGTGATGCAAAC }\end{array}$ & 141 \\
\hline ACTIN7 & NM_121018.4 & $\begin{array}{l}\text { F: ACAGGAAATGCTTCTAAGTGTGTCT } \\
\text { R: ACACAAGACTTCTTGACACAACCA }\end{array}$ & 171 \\
\hline
\end{tabular}

All primer sequences were taken from Dmitrović et al. (2015) 
Table 3. Hairy root regeneration from in vitro-grown shoots of four apple cultivars using wounding or dipping inoculation methods.

\begin{tabular}{|c|c|c|c|c|c|}
\hline Cultivar & $\begin{array}{l}\text { Number of } \\
\text { inoculated } \\
\text { shoots }\end{array}$ & $\begin{array}{l}\text { Percent of } \\
\text { shoots with } \\
\text { hairy roots } \\
\text { (\%) }\end{array}$ & $\begin{array}{l}\text { Total } \\
\text { number of } \\
\text { hairy root } \\
\text { lines }\end{array}$ & $\begin{array}{c}\text { Mean number of } \\
\text { hairy root lines per } \\
\text { shoot with hairy } \\
\text { roots }\end{array}$ & $\begin{array}{l}\text { Transformation } \\
\text { efficiency }(\%)\end{array}$ \\
\hline & \multicolumn{5}{|c|}{ Inoculation by wounding } \\
\hline Melrose & 94 & 18.1 & 66 & 3.9 & 70.2 \\
\hline $\begin{array}{l}\text { Golden } \\
\text { Delicious }\end{array}$ & 36 & 2.8 & 1 & 1.0 & 2.8 \\
\hline Čadel & 34 & 0.0 & 0 & 0.0 & 0.0 \\
\hline Gloster & 31 & 0.0 & 0 & 0.0 & 0.0 \\
\hline
\end{tabular}

Inoculation by dipping cut stem in bacterial suspension

\begin{tabular}{cccccc}
\hline Melrose & 30 & 3.3 & 1 & 1.0 & 3.3 \\
Golden & 28 & 39.3 & 11 & 1.0 & 39.3 \\
Delicious & 30 & 20.0 & 9 & 1.5 & 30.0 \\
Čadel & 10.0 & 3 & 1.0 & 10.0 \\
Gloster & 30 & & & & \\
\hline
\end{tabular}

Transformation efficiency was calculated as: (total number of hairy root lines/number of inoculated shoots) $\times 100$. 
Table 4. RT-PCR analysis of rol, aux and virDl genes expression in hairy root lines of Melrose

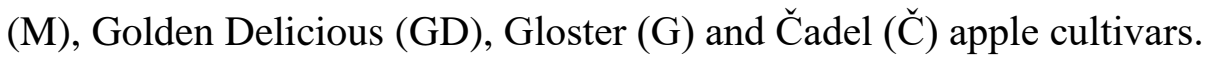

\begin{tabular}{|c|c|c|c|c|c|c|c|c|}
\hline \multirow{2}{*}{ Hairy root lines } & \multicolumn{4}{|c|}{$\mathbf{T}_{\mathrm{L}}-\mathbf{D N A}$} & \multicolumn{2}{|c|}{$\mathbf{T}_{\mathrm{R}}$-DNA } & \multirow{2}{*}{$\operatorname{virD1}$} & \multirow{2}{*}{ MdActin } \\
\hline & rolA & rolB & rolC & rolD & aux1 & $\operatorname{aux2}$ & & \\
\hline A.r.15834 & + & + & + & + & + & + & + & - \\
\hline M nt root & + & - & - & - & - & - & - & + \\
\hline GD nt root & - & - & + & - & - & - & - & + \\
\hline$\check{C}$ nt root & - & - & - & + & - & - & - & + \\
\hline G nt root & - & - & + & + & - & - & - & + \\
\hline M1 & + & + & + & + & - & - & - & + \\
\hline M2 & + & + & + & + & + & + & - & + \\
\hline M3 & + & + & + & + & + & - & - & + \\
\hline M4 & + & + & + & + & - & - & - & + \\
\hline M5 & + & + & + & + & + & - & - & + \\
\hline M6 & + & + & + & + & + & + & - & + \\
\hline M7 & + & + & + & + & - & + & - & + \\
\hline GD1 & + & + & + & + & - & + & - & + \\
\hline GD2 & + & + & + & + & - & + & - & + \\
\hline GD3 & + & + & + & + & + & + & - & + \\
\hline GD4 & + & + & + & + & - & + & - & + \\
\hline GD5 & + & + & + & + & - & - & - & + \\
\hline GD6 & + & + & + & + & - & - & - & + \\
\hline GD7 & + & + & + & + & - & + & - & + \\
\hline GD8 & + & + & + & + & - & + & - & + \\
\hline GD9 & + & + & + & + & - & + & - & + \\
\hline
\end{tabular}




\begin{tabular}{|c|c|c|c|c|c|c|c|c|}
\hline GD10 & + & + & + & + & - & + & - & + \\
\hline GD11 & + & + & + & + & - & - & - & + \\
\hline GD12 & + & + & + & + & - & + & - & + \\
\hline$\check{C} 1$ & + & + & + & + & - & + & - & + \\
\hline$\check{\mathrm{C}} 2$ & + & + & + & + & - & + & - & + \\
\hline$\check{\mathrm{C}} 3$ & + & + & + & + & - & - & - & + \\
\hline$\check{C} 4$ & + & + & + & + & - & + & - & + \\
\hline$\check{C} 5$ & + & + & + & + & - & - & - & + \\
\hline Č6 & + & + & + & + & - & + & - & + \\
\hline G1 & + & + & + & + & - & - & - & + \\
\hline G2 & + & + & + & + & - & - & - & + \\
\hline G3 & + & + & + & + & - & - & - & 4 \\
\hline
\end{tabular}

Positive control - A. rhizogenes strain 15834; Negative control - untransformed roots (nt root). 
Table 5. Phenolics in untransformed (control) roots, hairy root line GD12, and growth medium in which GD12 roots were maintained for four weeks.

\begin{tabular}{|c|c|c|c|c|}
\hline \multirow{2}{*}{ Phenolic } & \multicolumn{2}{|c|}{$\begin{array}{l}\text { Phenolic concentration } \\
\text { (ng mg-1 DW of roots) }\end{array}$} & \multirow{2}{*}{$\begin{array}{l}\text { Phenolics secreted } \\
\text { per mg of dry hairy } \\
\text { root } \\
\left(n g \text { mg}^{-1} \mathrm{DW}\right)\end{array}$} & \multirow{2}{*}{$\begin{array}{l}\text { Phenolics secreted } \\
\text { per mL of hairy root } \\
\text { growth medium } \\
\left(n g \mathbf{m L}^{-1}\right)\end{array}$} \\
\hline & Untransformed root & Hairy root & & \\
\hline Chlorogenic acid & $22.10 \pm 0.27$ & $22.10 \pm 1.70$ & $4.08 \pm 0.62$ & $8.82 \pm 0.68$ \\
\hline Caffeic acid & $29.99 \pm 0.68$ & $29.40 \pm 1.31$ & $6.71 \pm 0.87$ & $14.58 \pm 0.83$ \\
\hline Syringic acid & $7.17 \pm 0.08$ & $6.58 \pm 0.11$ & nd & nd \\
\hline$p$-Coumaric acid & $38.34 \pm 0.18$ & $38.37 \pm 0.92$ & nd & nd \\
\hline Ferulic acid & $6.16 \pm 1.51$ & $3.84 \pm 0.71$ & nd & nd \\
\hline Phloridzin & $1753.83 \pm 343.65$ & $2643.60 \pm 241.93$ & $3.34 \pm 0.73$ & $7.49 \pm 1.86$ \\
\hline Phloretin & nd & nd & $3.60 \pm 0.29$ & $8.01 \pm 1.051$ \\
\hline Rutin & $10.87 \pm 0.21$ & $10.84 \pm 0.28$ & nd & nd \\
\hline Isoquercitrin & $2.03 \pm 0.25$ & $1.51 \pm 0.59$ & $\mathrm{t}$ & $\mathrm{t}$ \\
\hline Kmf-3-glc & $0.64 \pm 0.36$ & $1.71 \pm 0.40$ & nd & nd \\
\hline Quercitrin & $8.29 \pm 1.98$ & $5.32 \pm 0.52$ & nd & nd \\
\hline Quercetin & $\mathrm{t}$ & $\mathrm{t}$ & $\mathrm{t}$ & $\mathrm{t}$ \\
\hline Naringenin & $\mathrm{t}$ & $\mathrm{t}$ & $\mathrm{t}$ & $\mathrm{t}$ \\
\hline
\end{tabular}

Values are presented as means $( \pm \mathrm{SE})$ of three biological replicates. Phenolic compound values for untransformed roots and hairy roots are not significantly different $(\mathrm{P} \leq 0.05)$ according to $t$-test; nd not detected; t- trace quantity. 